\title{
La ejecución propia e impropia de sentencias en el ambito contencioso-administrativo.
}

\author{
Federico A. Castillo Blanco \\ Catedrático de Derecho Administrativo \\ Universidad de Granada
}

SUMARIO: I. INTRODUGGIÓN: DE LA EJEGUGION DE SENTENCIAS COMO MANIFESTACIÓN DEL PRINCIPIO DE AUTOTUTELA DE LA ADMINISTRAGIÓN A LA GONSIDERACIÓN DE ESTA COMO ELEMENTO NUGLEAR DEL DEREGHO A LA TUTELA JUDICIAL EFECTIVA. II. PRESUPUESTOS Y REQUISITOS PROCESALES DE LA EJECUCIÓN DE SENTENCIAS. 1. Competencia y exclusividad jurisdiccional. 2. Carácter firme de la sentencia y liquidez en el caso de ejecución de condenas pecuniarias. 3. Que se exija, con carácter previo, la prestación de garantías. III. EL CUMPLIMIENTO VOLUNTARIO Y LA PROSGRIPGIÓN DE LAS GONDUGTAS ELUSIVAS. IV. EJEGUGIÓN DE CONDENAS PEGUNIARIAS. 1. La medidas tendentes a la agilización de la ejecución de las condenas pecuniarias. 2. Los límites a la ejecución de condenas pecuniarias. V. EJEGUCIÓN DE SENTENGIAS NO PECUNIARIAS. 1.- La ejecución de sentencias no pecuniarias. 2. La ejecución por equivalencia. 3. Medidas compulsivas tendentes al cumplimiento del fallo en obligaciones no pecuniarias. VI. LA EJECUCIÓN IMPROPIA.

RESUMEN: El objeto del trabajo que se presenta es dar cuenta del estado del arte en algunas de las principales cuestiones que la ejecución de sentencias, pecuniarias y no pecuniarias, presenta tras veinte años de la entrada en vigor de la LJCA y de las soluciones que los tribunales han establecido al objeto de dar respuesta a una tutela judicial efectiva.

PALABRAS CLAVE: tutela judicial efectiva, ejecución de sentencias, integridad, efectividad de la ejecución, inmodificabilidad de lo juzgado

ABSTRACT: The purpose of the work presented is to give an account of the state of the art in some of the main issues that the execution of sentences, pecuniary and non-pecuniary, presents twenty years after the entry into force of the LJCA and the solutions that the courts have been established in order to respond to effective judicial protection. 
KEY WORDS: effective judicial protection, execution of judgments, integrity, effectiveness of the execution, unmodifiability of the judged

\section{INTRODUGGIÓN: DE LA EJEGUGION DE SENTENGIAS COMO MANIFESTACIÓN DEL PRINCIPIO DE AUTOTUTELA DE LA ADMINISTRAGIÓN A LA GONSIDERAGIÓN DE ESTA COMO ELEMENTO NUCLEAR DEL DEREGHO A LA TUTELA JUDICIAL EFEGTIVA}

La Ley de 1956 confiaba, con carácter general, la ejecución de las sentencias a la Administración cuyos agentes eran responsables personalmente, civil y penalmente, de la misma en caso de incumplimiento o pasividad ${ }^{1}$. Podemos decir ahora, a la vista de lo que aconteció que hubo un cierto exceso de confianza en dicha solución.

El sistema, aunque a todas luces era susceptible de mejoras, lo cierto es que presentaba su mayor falla en la resistencia al cumplimiento recto e integro de los términos del fallo. No era infrecuente, en este sentido, la reproducción del acto anulado o la adopción de medidas que implicaban un relativo o insuficiente cumplimiento de los términos de la misma. La jurisprudencia de la época ofrece ejemplos al respecto ${ }^{2}$, pero también muestra las dudas de ésta sobre cómo proceder frente a dicha actuación ya que la misma oscilaba entre estimar inadmisible un nuevo recurso contencioso contra el nuevo acto por entender que se trataba de un problema de ejecución de sentencias, hasta considerarse incompetente para declarar formalmente nulos el nuevo acto o disposición a través de un simple incidente de ejecución que no estaba pensado para decretar directamente la nulidad de un segundo acto no enjuiciado ni para ordenar a la Administración, dentro del mismo, que declarase por sí la nulidad de ulteriores actos de reproducción. Situación que, en el día a día, determinaba la necesidad de presentación de sucesivos recursos que propiciaban en la práctica un real incumplimiento del fallo.

La citada situación fue determinante en el cambio de concepción operado por la reforma acontecida en $1998^{3}$. En este sentido, y en lo que a la ejecución de las reso-

\footnotetext{
Bien es cierto que el artículo 110 de la Ley de 1956 no excluía al tribunal sentenciador de la entera responsabilidad sobre la ejecución de la misma y, de esta forma, le atribuía la posibilidad de adoptar cuantas medidas, previa audiencia de las partes, fuesen adecuadas para promoverla y activarla, a petición de parte interesada, mientras no constare la total ejecución de la Sentencia y de todos sus pronunciamientos, salvo los supuestos de declaración de inejecución o suspensión.

2 De esta forma, puede verse las declaraciones contenidas en las SSTS de 27 de enero de 1965 (RJ 1965, 165) o la de 21 de junio de 1977 (RJ 1977, 2940). El propio Tribunal Constitucional denunció dicha situación y así pueden consultarse las SSTC 32/1982, de 7 de junio y 167/1987, de 28 de octubre.

Debe advertirse que muchas de las novedades legales que se incorporaron en ese momento tienen su origen en la reformulación del texto de 1956 llevada a cabo por la jurisprudencia del Tribunal
} 
luciones judiciales se refiere, la propia Exposición de Motivos de la Ley de 1998 hace unas declaraciones rotundas, que se traslucen en su texto ${ }^{4}$, y que recalcan la importancia del cumplimiento efectivo de lo declarado en la sentencia y como el contenido de la misma engarza con el derecho a la tutela judicial efectiva ${ }^{5}$.

Y es que tratándose la jurisdicción contencioso-administrativa, en lo esencial, de una jurisdicción revisora con los matices introducidos en 1998 por la nueva Ley reguladora de la misma, y partiendo cualquier enjuiciamiento de la legalidad de una actuación, inacción o disposición administrativa, el principio de autotutela de la Administración se hace presente, entre otras manifestaciones, en dos fundamentales, a saber: el primero en que, con carácter general, se ha de revisar necesariamente y con carácter previo antes de su análisis por los Tribunales el acto recurrido por la propia Administración autora del mismo ${ }^{6}$ y, en segundo lugar, en la de ejecutar la sentencia que se dicte ya se trate de una sentencia estimatoria de las pretensiones del deman-

Supremo y del Tribunal Constitucional a la luz del Texto Constitucional, singularmente a propósito de la incidencia en el sistema procesal en su conjunto del art. 24 (STC 67/1984, de 7 de junio, entre otras); ello no significa sin embargo, que la plasmación legal de las pautas y criterios jurisprudenciales no tenga valor por sí mismo, máxime cuando al legislador le compete muy especialmente velar por la seguridad jurídica (art. 9.3 de la Constitución).

4 La Ley 29/1998 de 13 de julio, reguladora de la Jurisdicción Contencioso-administrativa dedica el Capítulo IV del Título IV relativo al «Procedimiento contencioso-administrativo» a la «Ejecución de sentencias», rúbrica legal que formalmente resulta imprecisa, pues como expresamente prevé el art. 103 de la Ley, las disposiciones contenidas en este Capítulo son aplicables no sólo a las sentencias, sino a las «demás resoluciones judiciales» provistas de fuerza ejecutiva. Bien es cierto que, en otro sentido, y ya desde el punto de vista material o de los contenidos, los preceptos incluidos en el citado Capítulo no colman el sistema procesal ejecutivo, pues no en vano, es necesario acudir a otras partes de la norma para completar el sistema ejecutivo previsto en la norma.

Por otra parte, no puede desconocerse la supletoriedad de la Ley de Enjuiciamiento Civil (disp. final $\left.1^{\mathrm{a}}\right)$ que si bien no constituye una novedad respecto del régimen establecido en la Ley de 1956, sí cobra singular protagonismo para la integración de determinadas previsiones legales, tales como la determinación de los «propios medios» con que cuentan los órganos jurisdiccionales para «lograr la efectividad de lo mandado» (arts. 108.1 y 112.I).

5 Indica dicho texto que: La Ley ha realizado un importante esfuerzo para incrementar las garantías de ejecución de las sentencias, desde siempre una de las zonas grises de nuestro sistema contencioso-administrativo. El punto de partida reside en la imperiosa obligación de cumplir las resoluciones judiciales y colaborar en la ejecución de lo resuelto, que la Constitución prescribe, y en la potestad de los órganos judiciales de hacer ejecutar lo juzgado, que la propia Constitución les atribuye. Prescripciones que entroncan directamente con el derecho a la tutela judicial efectiva, ya que, como viene señalando la jurisprudencia, ese derecho no se satisface mediante una justicia meramente teórica, sino que conlleva el derecho a la ejecución puntual de lo fallado en sus propios términos.

6 De esta forma, y en lo que afecta al carácter revisor, se introdujeron los recursos contra la inactividad de la Administración y contra la vía de hecho, pero incluso en ambos supuestos, aunque advierte la ley que el enjuiciamiento se dirige contra esa inactividad o actividad sin sustento jurídico, hay una actuación previa ante la Administración, dándole la oportunidad de corregir su actuación, actuación previa administrativa que como es fácil imaginar va a ser cardinal en el posterior enjuiciamiento. 
dante, ya se trate de otra que tengan carácter desestimatorio. Bien es verdad que en ambos casos, y por sobre todo en el primero, con matices realmente relevantes respecto de la situación anterior tras una larga evolución histórica que, en el caso de esta última, implicó un cambio de concepción que se aleja del control del acto y se acerca a la protección del ciudadano de tal forma que la jurisdicción tendrá como función satisfacer, conforme a Derecho, las pretensiones que jurídicamente se le sometan ${ }^{7}$.

La ejecución de las sentencias forma parte de esta forma, y así lo han declarado con reiteración nuestros tribunales y la doctrina científica, del derecho a la tutela efectiva de los Jueces y Tribunales (por todas la STC 22/2009) ${ }^{8}$. Y así se ha reconocido y protegido, asimismo, por el propio Tribunal Europeo de Derechos Humanos ${ }^{9}$. $\mathrm{Y}$ es que, como fácilmente se podrá comprender, el derecho fundamental de acceso

De ineludible cita en este punto es el trabajo de MUÑOZ MACHADO, S., La reserva de jurisdicción, Madrid, Wolters Kluwer, 1989. Asimismo es de destacar los trabajos desarrollados en esta materia por BELTRAN DE FELIPE, M., El poder de sustitución en la ejecución de sentencias condenatorias de las Administración, Madrid, Civitas, 1995; GONZALEZ VARAS-IBANEZ, S. Comentarios a la Ley de la jurisdicción contencioso-administrativa: (Ley 29/1998, de 13 de julio), adaptados a la nueva concepción subjetiva, Madrid, Tecnos, 1999; MARTÍN DELGADO, I., La ejecución subrogatoria de las sentencias contencioso-administrativas, Madrid, Iustel, 2006; y FERNÁNDEZ TORRES, J.R., Historia legal de la jurisdicción contencioso-administrativa (1845-1998), Madrid, Iustel, 2007.

${ }^{8} \quad$ Establece este alto Tribunal que "Este Tribunal ha reiterado que el derecho a la ejecución de sentencias y demás resoluciones judiciales firmes constituye una manifestación del derecho a la tutela judicial efectiva, en tanto que garantía del cumplimiento de los mandatos que estas resoluciones judiciales contienen, lo que determina que este derecho tenga como presupuesto lógico y aun constitucional la intangibilidad de las resoluciones judiciales firmes y de las situaciones jurídicas por ellas declaradas. El derecho a que la ejecución de lo juzgado se lleve a cabo en sus propios términos, es decir, con sujeción al principio de inmodificabilidad de lo juzgado, se traduce, así, en un derecho que actúa como límite y fundamento que impide que los Jueces y Tribunales puedan revisar las sentencias y demás resoluciones al margen de los supuestos taxativamente previstos en la Ley (por todas, STC 86/2006, de 27 de marzo, F. 2).

9 En efecto, el Tribunal Europeo de Derechos Humanos entiende que la ejecución de las sentencias judiciales forma parte del derecho a la tutela judicial efectiva. Así, la Sentencia de 29 de julio de 2008 (TEDH 2008\54, caso Vidal Escoll y Guillán González contra Andorra), en su Apartado 69, viene a afirmar que:

"El Tribunal recuerda que, según su jurisprudencia, el derecho de acceso a un Tribunal sería ilusorio si el orden jurídico interno de un Estado Contratantes permitiera que una sentencia definitiva y obligatoria quedara inoperante en detrimento de una parte. La ejecución de una decisión o sentencia, de la jurisdicción que fuere, debe ser, por tanto, considerada como parte integrante del «proceso» en el sentido del artículo 6 (ver Sentencias Inmobiliaria Saffi contra Italia [GC], núm. 22774/1993, ap. 63, in fine, CEDH 1999-V, y Hornsby contra Grecia de 19 de marzo de 1997, Repertorio de sentencias y decisiones 1997-II, págs. 510511, ap. 40). En consecuencia, la ejecución de una decisión judicial no puede ser impedida, invalidada o retrasada de manera excesiva (Jasiunienè contra Lituania, núm. 41510/1998, ap. 27,6 de marzo de 2003)". Bien es cierto que el propio Tribunal reconocerá que "El derecho a la ejecución de la sentencia no puede, en cambio, obligar a un Estado a hacer ejecutar cada sentencia de carácter civil sea cual fuere y sean cueles fueren las circunstancias; sin embargo, le corresponde dotarse de un arsenal jurídico adecuado y suficiente para asegurar el respeto de las obligaciones positivas que le incumben”. De esta forma, aunque admite que un cambio en la situación de hecho constatada por una decisión judicial puede justificar excepcionalmente 
al proceso y a obtener la tutela jurisdiccional no serán efectivos y reales, si recaída una sentencia contraria a los intereses de la Administración, sus mandatos quedan insuficientemente cumplidos. Le corresponde al Estado que ejerce el monopolio de la violencia y prohíbe el ejercicio de la autodefensa emplear todos los medios a su alcance para garantizar la separación de poderes y el efectivo cumplimiento de las sentencias, pero muy especialmente si la condenada es la Administración pública. Por eso ha podido afirmarse que la ejecución procesal constituye en cierto sentido el punto culminante de la realización del derecho. Y es que, como recuerda el ATS de 16 de julio de 1991, «el derecho a la ejecución de sentencias no puede concebirse únicamente como un derecho del particular interesado en la ejecución, sino también como un esencial interés público implicado en el propio fundamento del Estado de Derecho».

Pues bien, la conclusión a partir de lo expuesto es inequívoca y ya se ha aludido a la misma más arriba. El derecho a la efectividad de la tutela judicial contemplado en el artículo 24.1 de la Constitución incluye el derecho a obtener la ejecución de lo resuelto en sus propios términos ${ }^{10}$. Aunque ciertamente se contempla una excepción: aquellos supuestos en que el cumplimiento del mismo no resultara posible de con-

la inejecución de una decisión, el Tribunal entiende que en el análisis que este realiza debe asegurarse de que los cambios esenciales en causa no son el resultado de una acción o de una inacción del Estado.

10 Para garantizar dicho paradigma, la propia ley jurisdiccional contempla una serie de garantías. En este sentido, por una parte, el artículo 112 LJCA contempla que las autoridades, funcionarios o agentes de la Administración Pública que infrinjan su deber fundamental de ejecutar lo dispuesto en sentencia firme pueden incurrir en responsabilidad. De esta forma, y en cuanto a su alcance, la STS de 1 de julio de 2008 por el Tribunal establece que: “ (...) el contenido de la ejecución de las sentencias debe extraerse de los términos en que se expresa el fallo de la misma (forma y términos de la misma), para alcanzar una determinada finalidad, que no es otra que conseguir el efecto pretendido en la declaración jurisdiccional, articulándose un amplio capítulo de medidas con la expresada finalidad, y señalando en tal sentido la Ley que tales amplias medidas vienen determinadas por lo que exija el cumplimiento de las declaraciones contenidas en el fallo.

La amplitud de los términos en que se expresa el texto legal permite deducir con absoluta claridad que el contenido de la ejecución de la sentencia tiene una doble perspectiva, por cuanto, de una parte, el Tribunal y la Administración han de llevar a cabo una determinada actividad jurídica, transformadora de los mandatos jurídicos a cuya anulación se ha procedido; y consecuencia de tal actividad, en determinadas ocasiones, será además preciso con un carácter complementario, llevar a cabo una actividad de índole material, transformadora de la realidad material, consecuencia del anterior pronunciamiento de nulidad y de la consiguiente actividad jurídica complementaria.

En síntesis, existe una finalidad que debe conseguirse en todo proceso de ejecución de sentencia; esa finalidad se obtiene de los términos en que el fallo de la sentencia se expresa e implica necesariamente una inicial actividad jurídica transformadora de los pronunciamientos jurídicos anulados, así como una consiguiente actividad material transformadora de la realidad fisica sobre la que recayeron los pronunciamientos jurídicos de referencia.

En consecuencia, el contenido exacto de la ejecución de la sentencia dependerá de los distintos pronunciamientos que la misma puede contener, sobre todo cuando se está en presencia de sentencias que tienen alguno de los contenidos estimatorios, a las que se refiere el artículo 71 de la vigente LJCA". 
formidad con lo establecido en el artículo 105 de la Ley 29/1998 ${ }^{11}$. De esta forma, a juicio de GÓMEZ-FERRER RINCÓN, la imposibilidad legal para la ejecución de sentencias en el orden contencioso- administrativo, solo cabe en determinados y tasados supuestos y siempre que exista una "razón atendible" lo que equivale a un bien o valor protegido constitucionalmente (STG 73/2000, de 14 de marzo) ${ }^{12}$.

En este sentido, y como venimos exponiendo, el Tribunal Constitucional ha venido integrando el derecho a la ejecución del fallo dentro del derecho fundamental a la tutela judicial efectiva del artículo 24 de la Constitución, configurándolo como un derecho subjetivo del justiciable que tiene como presupuesto lógico y constitucional la intangibilidad de las resoluciones judiciales firmes y de las situaciones jurídicas por ellas declaradas, y, además, actúa como límite y fundamento que impide que los jueces y tribunales puedan revisar las sentencias y demás resoluciones al margen de los supuestos taxativamente previstos en la Ley.

Por tanto, el derecho fundamental a la tutela judicial efectiva también se concreta en fase de ejecución en el cumplimiento del fallo judicial, para evitar que la sentencia firme se convierta en una mera e ineficaz declaración formal. Pero es que, además, en una evolución lógica de su doctrina, para el Tribunal Constitucional poco importa que el fallo de la sentencia a ejecutar se limite a anular el acto administrativo impugnado, sin ordenar expresamente ninguna de aquellas posibles actuaciones que puede exigir o conllevar tal anulación. Es también doctrina constitucional la que integra en el derecho fundamental a la ejecución de las sentencias la llamada garantía de interpretación finalista del fallo que infiera de él todas sus naturales consecuencias. Así, en un momento posterior, el Tribunal Constitucional, entre otras, SSTC 125/1987 (FJ 2) 148/1989 (FJ 4), y 92/1998 (FJ 2), se preocupará por establecer la necesaria correlación que debe existir entre los hechos y antecedentes, los fundamentos jurídicos, y la parte dispositiva de la sentencia firme para, sin alterar los términos del debate ni incluir cuestiones no debatidas (no cabe adicionar decisiones que excedan o sobrepasen lo decidido con fuerza de cosa juzgada, STC 99/1995), obtener del fallo todas y cada una de sus consecuencias, en una interpretación finalista que materialice el principio pro accione y sirva al de economía procesal, evitando

11 La posible concurrencia de causas de orden material o legal que impiden el cumplimiento fiel de las sentencias, ha sido recogida tanto por el artículo 18.2 LOPJ, aplicable a todos los procesos judiciales en general, como particularmente y para el proceso contencioso-administrativo por el artículo 105.2 LJCA. Puede verse en este punto el trabajo de RAZQUIN LIZÁRRAGA, J. A., "Tutela judicial efectiva e imposibilidad legal de ejecución de sentencias en materia de urbanismo", en Revista Aranzadi Doctrinal, n 3, Ed. Aranzadi, Pamplona, 2009.

12 GÓMEZ-FERRER RINCÓN, R., La imposibilidad de ejecución de sentencias en el proceso contencioso-administrativo, ThomsonCivitas, Madrid, 2008. 
así la obligada apertura de nuevos procesos cuyas pretensiones pudieron y debieron resolverse con este espíritu.

Pero, a pesar de ello, lo cierto y sin embargo es que en el ámbito de la jurisdicción contencioso-administrativa, la ejecución de sentencias sigue presentando una especial conflictividad ${ }^{13}$, derivada fundamentalmente del hecho de que se trata de una actividad que debe desarrollar en principio la propia Administración condenada, por lo que existe una serie de cautelas y garantías para que la sentencia se ejecute correctamente, concretadas en la sanción de nulidad de pleno derecho de las disposiciones y actos contrarios a la sentencia, la regulación de una vía incidental y el establecimiento de la potestad sustitutoria del juez o tribunal en los casos en que la Administración pública no cumpla la sentencia, en la misma línea que venía observándose en la mayoría de los países de nuestro entorno.

Nos resta, para finalizar esta introducción, advertir que no abordaremos en nuestro análisis la ejecución provisional de sentencias, una institución íntimamente relacionada con los efectos suspensivos de los recursos interpuestos contra las sentencias, ni tampoco abordaremos las singularidades que presenta la ejecución de sentencias en el ámbito urbanístico que son objeto de otros trabajos en este número especial de la Revista Andaluza de Administración Pública. Asimismo, y dada la extensión de este trabajo, tampoco se analizarán cuestiones que, como el proceso incidental en sí mismo y las cuestiones que pueden plantearse en éste, la extensión a terceros de la cosa juzgada o el denominado pleito "testigo", excederían de las pretensiones de este trabajo cuyo objeto, más bien, es dar cuenta del estado del arte en la ejecución de sentencias tras veinte años de la entrada en vigor de la LJCA.

\section{PRESUPUESTOS Y REQUISITOS PROCESALES DE LA EJECU- GIÓN DE SENTENGIAS}

\section{Competencia y exclusividad jurisdiccional}

Respecto de la competencia, los arts. 7.1 y 103.1 de la Ley 29/1998, de 13 de julio, reguladora de la Jurisdicción Contencioso-Administrativa (en adelante LJCA) consagran una norma de competencia funcional, en virtud de la cual la ejecución corresponde al juez o Tribunal que hubiere dictado la sentencia en primera o única instancia. Para el tratamiento procesal de la competencia son plenamente aplicables las normas generales (art. 7.2).

13 Dicha dificultad subsiste y ha sido puesta de manifiesto, entre otros, por SUAREZ GARCÍA, J., "Algunos ejemplos prácticos de la difícil ejecución de sentencias contencioso-administrativas", en el volumen colectivo La ejecución de sentencias contencioso-administrativas (coord. SANCHEZ LAMELAS, A.), Thompson-Aranzadi, Navarra, 2006, págs. 205 y ss. 
Dichas previsiones, como ya se puede intuir, se separaban radicalmente del texto del art. 103 de la Ley de 1956, según el cual, «la ejecución de las sentencias corresponderá al órgano que hubiere dictado el acto o la disposición objeto del recurso» $^{14}$. En cualquier caso, de la actual regulación jurisdiccional se desprende, sin necesidad de mayor razonamiento al respecto, que la potestad de hacer ejecutar las sentencias en el ámbito contencioso-administrativo corresponde hoy a los órganos jurisdiccionales de dicho orden una vez superada la regulación que, en esta concreta materia, contenía la LJCA de $1956^{15}$.

El artículo 103.1 LJCA, no ofrece dudas al respecto y remite como se ha apuntado más arriba al órgano jurisdiccional que haya conocido en primera o en única instancia dicha función. Todo ello, también hemos de dejarlo claro, sin perjuicio de la colaboración de la Administración, bien es cierto que ésta ve limitada su función a la de un simple ejecutor material de lo resuelto por el órgano jurisdiccional lo que limita, como puede imaginarse, sus facultades que no van más allá de la estricta ejecución del fallo sin que pueda introducir modificaciones en el contenido de éste que desvirtúen lo ya resuelto por el órgano jurisdiccional. Como ha indicado TORNOS MAS la Administración no actúa con potestades propias ${ }^{16}$, y es que, efectivamente, procede en cumplimiento de un deber actuando sometida plenamente al control de los tribunales. Pero, además, esas facultades colaborativas atribuidas a la Administración autora de la situación rechazada judicialmente han de ser interpretadas en forma restrictiva lo que veta, salvo en los supuestos de lo que más adelante vamos a dar cuenta, que se proceda a un cumplimiento "aparente" del fallo de la sentencia dictada.

No obstante, la Ley de 1998 amplía y refuerza la legitimación de «las personas afectadas» por el fallo judicial (art. 104.2), declaración a la que siguen otras manifestaciones que vienen a reconocer la legitimación de sujetos que no han tenido

14 Aunque la jurisprudencia del Tribunal Constitucional hubo de interpretar su tenor literal a la luz de los principios constitucionales - explicitando que no suponía la atribución al órgano administrativo de una potestad de ejecución (sentencia del Tribunal Constitucional 67/1984 de 7 de junio ) -, lo cierto es que la redacción legal dada en 1998 ratifica los poderes del juez ejecutor y despeja cualquier duda sobre una eventual o hipotética potestad ejecutiva de carácter administrativo; no en vano, el control jurisdiccional de la ejecución es patente, entre otros, en el art. 104.1 de la ley, que además de exigir al órgano administrativo «el cumplimiento de las declaraciones contenidas en el fallo», le impone la comunicación al juez, no sólo de la recepción de la sentencia, sino del órgano responsable de su cumplimiento.

${ }_{15}$ Que había sido denunciado por la más cualificada doctrina Eduardo GARCÍA DE ENTERRÍA y Tomás-R. FERNÁNDEZ RODRÍGUEZ: Curso de Derecho Administrativo, Ed. Civitas. Madrid, 2000, por oponerse a las previsiones establecidas constitucionalmente en el artículo $117 \mathrm{CE}$

16 TORNOS MÁS, J., Comentarios a la Ley de la furisdicción Contencioso-Administrativa, Civitas, Madrid, 1999, pág. 30. 
la condición de partes procesales ${ }^{17}$. De esta forma, se reconoce la legitimación que asiste a «los interesados» para instar la reposición de los actos administrativos que contravengan el fallo judicial (art. 108.2), o a «las personas afectadas» para promover incidentes en ejecución (art. 109.1); a mayor abundamiento, repárese en la audiencia a las partes y demás «interesados» que el juez ejecutor debe conceder con carácter previo a la resolución sobre la eventualmente alegada imposibilidad de cumplimiento (art. 105.2).

\section{Garácter firme de la sentencia y liquidez en el caso de ejecución de condenas pecuniarias}

La acción ejecutiva se funda en todo caso en una sentencia firme de condena -ya se trate de contenido pecuniario o no pecuniario que es el título ejecutivo-, no constituyendo auténtica ejecución procesal las actividades judiciales siguientes a la efectividad de sentencias meramente declarativas (inscripciones registrales y publicaciones en periódicos) que constituyen más bien supuestos de ejecución impropia a los que al final de este trabajo nos referiremos y es que, como ha reconocido el Tribunal Supremo, sólo las sentencias de condena son realmente susceptibles de ejecución forzosa. Las sentencias meramente declarativas o constitutivas, en cambio, no pueden ser objeto de ejecución forzosa, toda vez que ellas mismas «consuman la tutela judicial» ${ }^{18}$, bien es cierto que dicha conclusión ha sido matizada más recientemente

17 Como se indica en el ATS de 27 de noviembre de 2006, (recurso 309/2004): «Para responder a las dudas descritas sobre la legitimación hemos de partir del dato incontestable de que el promotor del incidente no fue parte en el proceso que culminó con la sentencia de cuya ejecución ahora se trata. Pero no es menos cierto que la ejecución del fallo afecta a sus intereses legítimos, pues al haberse acordado la retroacción de actuaciones en el procedimiento administrativo de provisión de la plaza a la que aspira junto con otros candidatos, los trámites subsiguientes a esa retroacción inciden directamente en su esfera de intereses. El tema controvertido se reduce, por eso, a determinar si la posición de interesado en la ejecución del fallo constituye por sí misma título legitimador para instar un incidente de ejecución como el que examinamos, aun no habiendo sido parte en el proceso principal, o tal posibilidad está circunscrita exclusivamente a quienes tuvieron la condición de partes procesales.

La cuestión, ciertamente polémica, ha sido resuelta por la sentencia del Pleno de esta Sala Tercera de 7 de junio de 2005 en la que se apuntó que las "personas afectadas" por el fallo son aquéllas que puedan ver menoscabados o perjudicados sus derechos o sus intereses legítimos por efecto de la ejecución o de la inejecución de la sentencia, añadiéndose que esas personas "afectadas" tienen legitimación para promover o intervenir en el proceso de ejecución, como parte activa, sin necesidad de haber sido previamente parte en el proceso de conocimiento, y eso aún en el supuesto de que no hubieran impugnado por su cuenta la resolución objeto del litigio ni se hubieran personado en las actuaciones del proceso declarativo, pudiendo haber hecho tanto una cosa como la otra».

18 Entre otras, STS de 22 de diciembre de 2005 (recurso de casación núm. 6671/2002) y STS de 23 de abril de 2010 (recurso de casación núm. 3648/2008). 
por nuestros tribunales (por todas puede verse la STS de 4 de marzo de 2011, rec. $3996 / 2010)^{19}$.

Respecto de los títulos ejecutivos, todos los previstos son de naturaleza jurisdiccional, a saber: la sentencia firme de condena (art. 104.1), la sentencia definitiva declarada provisionalmente ejecutable (arts. 84 y 91), el auto que aprueba lo convenido en «conciliación intraprocesal» (arts. 77.3 y 113), el de imposición de multas coercitivas (arts. 48.9 y 112 a) y el aprobatorio de la tasación de costas (art. 139.4).

El deber impuesto a la Administración de dar cumplimiento ex officio a la sentencia firme no quiere decir, en opinión de una parte importante de la doctrina, la pérdida de vigencia del principio dispositivo, pues en todo caso sigue asistiendo a las partes el poder de disposición sobre la acción ejecutiva; además de la posibilidad de instar la ejecución forzosa si transcurrieren dos meses sin que la Administración hubiere accedido al cumplimiento voluntario del fallo judicial.

No obstante dicha interpretación ha sido, al menos matizada, por los tribunales al interpretar la aplicación a la ejecución de sentencias, en el ámbito contencioso-administrativo, del art. 518 LEG que establece la caducidad quinquenal ${ }^{20}$. De esta forma, en la STS de 25 de noviembre de 2009 (Rec. 6237/2007), se subraya la diferencia esencial entre la ejecución en el proceso civil, a instancia de parte, y la ejecución en el recurso contencioso administrativo, siempre de oficio ${ }^{21}$.

$19 \quad$ El TS declara que: "es preciso perfilar la incidencia que en la ejecución puede tener el que la sentencia sea de condena o sea declarativa o constitutiva, pues estas últimas han sido tradicionalmente consideradas como sentencias que originan la denominada ejecución impropia, ya que producen efectos por la mera declaración judicial de nulidad o de anulabilidad del acto o disposición impugnada, y sólo serían susceptibles de una ejecución propia aquellas que condenan a la Administración al cumplimiento de una determinada prestación.

Tal tesis, sin embargo, debe ser objeto de algunas precisiones, ya que la mera conclusión de que no precisan ejecución alguna las sentencias que se limitan a declarar la nulidad de un acto administrativo (declarativas) o a anular un acto administrativo (constitutivas) está alejada de la realidad del proceso contencioso-administrativo. Pues, de una parte, el carácter meramente constitutivo o declarativo ---y no de condena--- de una sentencia anulatoria de un acto está vinculado a que la pretensión estimada sea simplemente anulatoria y no comporte el reconocimiento de una situación jurídica individualizada. Por otra, no es posible ignorar que, incluso cuando la pretensión es sólo de anulación, el que un particular pueda hacer valer un fallo estimatorio de tal naturaleza frente a la supremacía de la Administración y frente a terceros, puede exigir una actividad ejecutiva. Y, en cualquier caso, el propio pronunciamiento judicial anulatorio es susceptible de quedar desvirtuado por una ulterior actuación administrativa constitutiva de la llamada "inejecución indirecta", si concurren los requisitos que han quedado expuestos".

20 Manteniendo la aplicabilidad de esta caducidad se manifiesta, sin embargo, LÓPEZ GIL, M., Avances en la ejecución de sentencias contra la Administración, Thompson-Aranzadi, Navarra, 2004, pág. 260.

$21 \quad$ La sentencia de 27 de enero de 2010 (Rec. 6431/2008), se expresa de forma contundente al defender la ejecución de oficio y rechazar la pretendida aplicación del art. 518 LEC invocada por la Administración. Afirma en su FJ 60: "la ejecución de las sentencias de este orden jurisdiccional contenciosoadministrativo se inicia de oficio mediante la comunicación que de modo necesario ha de hacer el Juzgado 
La sentencia insiste en que «frente a la necesidad de solicitud de parte mediante nueva demanda en el procedimiento civil, en el recurso contencioso administrativo es el Tribunal de oficio el que está obligado iniciar el incidente de ejecución de sentencia» $\left(\mathrm{FJ} 6^{\circ}\right.$ ). Y tras la trascripción del art. 104 LJCA, en su redacción originaria y en la adoptada tras la Ley 13/2009, de 3 de noviembre, declara que el plazo de ejecución voluntaria de la sentencia se inicia tras la comunicación a la administración autora del acto impugnado. No es «el momento de la notificación de la sentencia al representante procesal de la Administración el que determina el inicio del cómputo del plazo para la ejecución voluntaria de la sentencia por parte de la Administración demandada» $\left(\mathrm{FJ} \mathrm{6}^{\circ}\right)$. A la vista del art. 104 LJCA entiende que tal momento será el de la comunicación realizada de oficio de la misma sentencia al órgano «que hubiere realizado la actividad objeto del recurso».

Y concluye que «en toda dicha actuación no existe intervención de la parte recurrente, por cuanto se trata de una actuación de oficio del Tribunal que debería determinar igualmente sin intervención de parte la inmediata ejecución de la sentencia...» $\left.\left[\mathrm{FJ} 6^{\circ} \mathrm{b}\right)\right]^{22}$.

La liquidez de la condena constituye, asimismo, un presupuesto ineludible en el caso de la ejecución de condenas pecuniarias, si bien la determinación cuantitativa

\footnotetext{
o Tribunal al órgano administrativo que hubiera realizado la actividad objeto del recurso a fin de que, entre otros extremos, lleve a puro y debido efecto la sentencia y practique lo que exija el cumplimiento de las declaraciones contenidas en su fallo (art. 104.1 de la Ley de la Jurisdicción). Y se desenvuelve después en el modo y forma que prescriben los artículos siguientes, con la previsión, incluida en el 109.1, de que los incidentes que regula pueden promoverse mientras no conste en autos la total ejecución de la sentencia. Normas específicas que hacen inaplicable en este orden jurisdiccional contencioso-administrativo el plazo quinquenal de caducidad previsto en aquel art. 518 de la LEC".

22 Razona que tanto la estructura como los principios del proceso contencioso administrativo son distintos del procedimiento civil. Y añade la existencia de otros elementos que conducen a poner de manifiesto las diferencias procedimentales que hacen inviable la aplicación supletoria del art. 518 LEC. Parte de la potencialidad del vigente art. 103.1 LJCA que transforma la potestad de ejecutar las sentencias en potestad jurisdiccional y, sobre todo, del sentido de la comunicación (art. 104.1) que de oficio y luego que sea firme la sentencia, el Tribunal (a través del Secretario del mismo) remite al órgano que hubiere realizado la actividad objeto del recurso, a fin de que lleve la sentencia «a puro y debido efecto y practique lo que exija el cumplimiento de las declaraciones contenidas en el fallo».

Reputa contrasentido ampliar la legitimación para la ejecución definitiva de las sentencias a personas afectadas por la misma, que no han sido parte en el litigio (doctrina sentada en la sentencia del Pleno de la Sala 3.a de 7 de junio de 2005, Rec. 2492/2003) e impedir, al mismo tiempo, que el Tribunal que ha resuelto el litigio no lo pueda realizar de oficio en el ejercicio de su potestad jurisdiccional. Por ello, de los términos del art. 108 LJCA, en conjunción con los arts. 103.4 y 5, 104.2 más el art. 112, concluye que «el legislador amplía considerablemente la legitimación para llevar a cabo la solicitud de ejecución forzosa de las sentencias, por cuanto no limita la misma a quienes exclusivamente hubieran sido partes en el procedimiento, sino que, como bien se expresa, se amplía a las personas afectadas por la sentencia dictada. Legitimación, obviamente inviable en el procedimiento civil» [FJ 6.o c)].
} 
en que consiste puede ser inmediata -con fijación de la cuantía que deba satisfacerse ${ }^{23}$ -, o mediata -con establecimiento de las bases que sirvan para su fijación en ejecución de sentencias- (art. 71.1 d) ${ }^{24}$, en cuyo caso será de aplicación supletoria la Ley de Enjuiciamiento Civil. En todo caso, con base en la supletoriedad de la Ley de Enjuiciamiento Civil, puede afirmarse el deber judicial de efectuar aquella determinación, admitiéndose las condenas con reserva de cuantificación ulterior sólo en caso de que aquélla no fuere posible en el proceso declarativo.

\section{Que se exija, con carácter previo, la prestación de garantías ${ }^{25}$}

Esta novedad, en el régimen jurídico de la ejecución de sentencias, fue introducida por el apartado cuatro de la disposición final tercera de la LO 7/2015, de 21 de julio, por la que se modifica la LOPJ y ciñe su radio de acción al ámbito urbanístico por lo que, sin perjuicio de dar cuenta de la misma, remitamos a otro trabajo de este número su consideración particular.

En efecto, el artículo 108.3 prevé que el Juez o Tribunal, en los casos en que, además de declarar contraria a la normativa la construcción de un inmueble ordene motivadamente la demolición del mismo y la reposición a su estado originario de la realidad física alterada exigirá, como condición previa a la demolición, y salvo que una situación de peligro inminente lo impidiera, la prestación de garantías suficientes para responder del pago de las indemnizaciones debidas a terceros de buena fe.

Como se sabe esta modificación legislativa es producto de situaciones, en materia de ejecución de ejecución de sentencias urbanísticas, que son bien conocidas y que tuvieron una especial incidencia durante la pasada época del denominado "boom" del ladrillo producto de la anulación, bien de planes de ordenación urbanística, bien de licencias urbanísticas, que afectaban a terceros adquirentes de buena $\mathrm{fe}^{26}$.

${ }^{23}$ En particular, respecto de la cuantificación de los daños y perjuicios téngase en cuenta que la individualización y cuantificación de los mismos puede ser instada en el acto de la vista o en el escrito de conclusiones «si constasen ya probados en autos» (art. 65.3).

24 Puede, de esta forma, establecerse una cuantía máxima sin que ello implique el devengo de intereses desde la fecha de notificación de la sentencia (STS 23 de enero de 2015. RJ 3209).

${ }_{25}$ Un comentario sobre este punto puede consultarse en BERROCAL ACEDO, A., “¿Integra el artículo 108.3 LJCA un supuesto de suspensión de la ejecución de sentencia?", Actualidad administrativa, No 2, 2018 y CHAVES GARCÍA, J. R.: (5 de octubre de 2015): "Ejecución de sentencias de demolición tras el novedoso 108.3 LJCA": https://delajusticia.com/2015/10/05/ejecucion-de-sentencias-de-demolicion-tras-el-novedosoarticulo-108-3-ljca/.

26 En concreto, el origen de tal modificación normativa tiene su base en la anulación por el TC de la Ley de Cantabria 2/2011, de 25 de junio, de Ordenación Territorial y Régimen Urbanístico del Suelo de Cantabria que, ante la existencia de terceros adquirentes de buena fe que se habían visto afectados por resoluciones firmes de demolición de las mismas, resultando que en la mayoría de los casos los propietarios últimos resultaban ajenos a la comisión de la infracción dio una solución pretendiendo, en suma, una amnistía para las edificaciones ilegales (llevando a tal fin modificaciones normativas tendentes a paliar los per- 
En la mayor parte de las ocasiones los interesados no habían sido informados de la situación de ilegalidad de su vivienda al no haberse instado la anotación de la demanda interpuesta frente a las correspondientes licencias y la posición de nuestro Tribunal Supremo era, hasta ese momento, inequívoca respecto de que la protección del art. 34 de la LH no alcanzaba a los propietarios afectados por la anulación de las licencias y la orden de demolición subsiguiente como consecuencia de la misma, puesto que para el Tribunal Supremo sobre la protección hipotecaria prevalecía el cumplimiento de los deberes urbanísticos en los que queda subrogado en nuevo pro$\operatorname{pietario}^{27}$.

Lo cierto, y sin perjuicio de la remisión efectuada, es que, sin perjuicio de la bondad de la medida, se pueden producir situaciones conflictivas como las derivadas de la indeterminación de quién será el obligado a prestar la fianza, su entrada en vigor, quien puede ser considerado tercero de buena fe, etc., y, en cualquier caso, hay que concluir que la propia existencia de la misma podría suponer, de hecho, una condición suspensiva a la ejecución de las sentencias en materia urbanística que pudiera

juicios causados a aquellos adquirentes de buena fe cuyas viviendas se ven afectadas por sentencias firmes de derribo) y pretendiendo garantizarles en virtud del instituto resarcitorio patrimonial una indemnización y su puesta a disposición previo a la ejecución de las sentencias de derribo

Pues bien el Tribunal Constitucional, en su sentencia de 22 de abril de 2013 declara inconstitucional el pfo. 5.o del apartado cuarto de la DA 6.a (respecto a procesos de ejecución judicial) así como, por la conexión existente entre ambos, el apartado quinto de la misma DA 6.a, por las siguientes razones: «... la norma cuestionada incide en la regulación de la ejecución de sentencias mediante la introducción de un trámite (el de la eventual responsabilidad patrimonial en que pudiera haber incurrido la Administración urbanística) ajeno a la propia ejecución de la Sentencia y que tiene el efecto de paralizar la misma mientras sustancia, decide y, en su caso, ejecuta mediante el pago.

Tal regulación (...) no tiene cobertura competencial en los títulos aducidos por los órganos de la Comunidad Autónoma de modo que se invade la competencia exclusiva del Estado en materia de legislación procesal prevista en el art. 149.1.6 CE, sin que, tal como admiten todos los que han intervenido en este proceso constitucional, concurra especialidad alguna en el derecho sustantivo autonómico que lo justifique en términos constitucionalmente admisibles conforme al indicado precepto constitucional;

(...) lo que resulta incompatible con la reserva estatal en materia de legislación procesal art. 149.1.6 CE es que el legislador autonómico establezca una causa de suspensión o aplazamiento de la ejecución de las sentencias que han de ejecutarse mediante el derribo de edificaciones, máxime cuando el precepto legal no condiciona la efectividad de la demolición judicialmente acordada al transcurso de los plazos para resolver el expediente de responsabilidad patrimonial, sino a su efectiva resolución y al pago de la indemnización acordada, de suerte que la ejecución de la sentencia termina por escapar del control judicial, único competente para hacer ejecutar lo juzgado a tenor de lo dispuesto en el art. 117.3 CE que resulta igualmente vulnerado.»

27 La doctrina del Tribunal Supremo se basaba, en definitiva, en tres grandes argumentos (SSTS 12 de mayo de 2006 y 4 de febrero de 2009): en primer lugar, que los terceros adquirentes no están protegidos frente a la demolición por el art. 34 de la Ley Hipotecaria; en segundo término, que los terceros afectados tienen la obligación de soportar el derribo con base en el principio de subrogación urbanística; y, por último, que el adquirente tiene la obligación de conocer la situación urbanística de la vivienda. 
ser contraria al derecho a la tutela judicial efectiva tal y como ha sido conceptuada por el Tribunal Constitucional según lo hasta aquí expuesto ${ }^{28}$.

\section{EL CUMPLIMIENTO VOLUNTARIO Y LA PROSCRIPGIÓN DE LAS CONDUGTAS ELUSIVAS.}

La LJCA impone a la Administración el deber de llevar el fallo de la sentencia, una vez firme, «a puro y debido efecto», en los diez días siguientes a su recepción, tras haber acusado recibo de su comunicación e indicado el órgano encargado de cumplirlo (art. 104.1). Se trata, pues, de un auténtico deber de la Administración de proceder ex officio a cumplimentar la sentencia, lo cual no necesariamente supone merma del principio dispositivo, por cuanto transcurridos dos meses desde la comunicación «cualquiera de las partes y personas afectadas podrá instar su ejecución forzosa» (art. 104.2) $)^{29}$.

Esta disposición de carácter general que la Ley establece sin embargo es objeto de excepción estableciéndose, a estos efectos, dos reglas singulares: en primer término, el dies a quo del plazo para instar la ejecución empezará a correr transcurrido el plazo fijado en la propia sentencia para su ejecución de conformidad con lo establecido en los arts. 71.1 c) y 104.3 que permiten fijar un plazo inferior a dos meses, atendiendo a la naturaleza de lo reclamado y a la efectividad de la sentencia, cuando éste haga ineficaz el fallo o cause grave perjuicio; en segundo término, la ampliación del plazo para instar la ejecución tratándose de condenas pecuniarias (art. 106.4).

En todo caso, el deber impuesto a la Administración de cumplimentar de inmediato el fallo judicial lo es respecto, como se señalaba con anterioridad, de las resoluciones firmes; de ahí, que la ejecución provisional de sentencias deba actuarse necesariamente a instancia de parte interesada (arts. 84.1. y 91.1). Respecto de los

$28 \quad$ La STS de 17 de septiembre de 2018 (recurso n ${ }^{\circ}$ 477/2016), desestima que el art. 108.3 de la LJCA se trate de un supuesto de suspensión o de inejecución de sentencia dado que, razona el tribunal, no resultaría conforme ni compatible con el derecho a la tutela judicial efectiva, el cual se concreta en un derecho de contenido prestacional a que la sentencia sea llevada a su debido efecto y en sus propios términos. De lo que concluye que se trata de dotar al juez, una vez acreditada la necesidad, adecuación y proporcionalidad de la demolición, de determinados poderes en orden a que dicha demolición no haya de causar efectos irreparables en los terceros adquirentes de buena fe. Esto es, sigue diciendo el Tribunal, mientras el art. 105 lo que prevé son supuestos de inejecución de sentencias por causas legales o materiales, el art. 108.3 se sitúa en un momento posterior del proceso de ejecución, en cuanto se incluye en un precepto que recoge los poderes del juez para que la ejecución se lleve a efecto, con lo cual se convierte en una fase más de la ejecución, pero nunca en un impedimento, ni siquiera temporal para la ejecución de la sentencia.

29 Sobre la inobservancia del plazo de dos meses la STS de 29 de diciembre de 2015 (RC 4179/2014), sintetiza su evolutiva doctrina en relación con los efectos que acarrea el incumplimiento del plazo con que cuenta la Administración, o los interesados en algunos supuestos, para el planteamiento al Tribunal de la concurrencia de causa de imposibilidad legal o material de ejecución de la sentencia. 
autos que aprueban lo convenido entre las partes en conciliación, éstas podrán instar la ejecución transcurrido el plazo acordado para su cumplimiento ya que el Auto que aprueba dicho acuerdo es directamente ejecutable y su cumplimiento es obligatorio (art. 113.1); en defecto de pacto, la parte perjudicada podrá instar la ejecución transcurridos dos meses desde el preceptivo requerimiento (art. 113.2) ${ }^{30}$.

Como bien explicita la Exposición de Motivos, «la negativa, expresa o implícita, a cumplir una resolución judicial constituye un atentado a la Constitución frente a la que no caben excusas». De ahí que este cumplimiento de lo establecido en sentencia venga presidido por tres principios informadores: integridad, efectividad de la ejecución e inmodificabilidad de lo juzgado que se traducen en un derecho subjetivo de la parte, o de otros interesados ${ }^{31}$, a su cumplimiento; principios que, a su vez, se manifiestan en distintos preceptos, a saber: en el art. 103.3 al aludir a la «debida y completa ejecución de lo resuelto»; en el art. 112 a) a propósito de la reiteración de las multas coercitivas que el juez puede imponer a la Administración «hasta la completa ejecución del fallo judicial»; en el art. 104.1 al desplazar sobre el órgano que hubiera dictado el acto impugnado la carga de practicar «lo que exija el cumplimiento de las declaraciones contenidas en el fallo»; en las formas específicas de ejecución de sentencias de condena no pecuniaria previstas en el art. 108; o, por fin, y de una forma más genérica, al referirse a la adopción judicial de «las medidas necesarias para lograr la efectividad de lo mandado» (art. 112).

Los citados principios, además, revisten un doble carácter: el primero, de carácter positivo, por cuanto las sentencias -y demás resoluciones ejecutivas- se ejecutarán «en sus propios términos», según establece el art. 18.2 LOPJ que, como se recordará, supuso la eliminación de la potestad gubernativa de suspensión o inejecución de las sentencias (arts. 105.1 b y $c$ de la Ley de 1956), extremo éste corroborado ahora por el art. 105.1. LJCA en virtud del cual "No podrá suspenderse el cumplimiento ni declararse la inejecución total o parcial del fallo". Pero, como se ha expuesto, los citados principios tienen un segundo carácter, en este caso de carácter negativo, al proscribir las «ejecuciones aparentes». Y es que una forma de inejecución muy extendida de las sentencias condenatorias deriva de la tendencia de la Administración a esquivar la declaración judicial de nulidad de un acto administrativo recurriendo al mecanismo de la subsanación de defectos, la reproducción total o parcial del acto anulado o la emisión de otros actos de contenido incompatible con la plena eficacia del fallo,

30 Pueden verse respecto de este acuerdo en conciliación la STSJ de Castilla y León de 31 de mayo de 2002 (JUR 2002/159339) o el Auto del TSJ del País Vasco de 24 de noviembre de 2004 (JUR 2005, 39850).

31 Así se señala, con abundante cita de jurisprudencia, por ARANGUREN PÉREZ, I. Y GON-

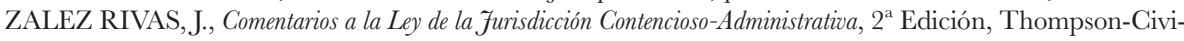
tas, Navarra, 2008, págs. 1118 y ss. 
actitud denunciada por el Tribunal Supremo en su Sentencia de 5 de junio de 2014, (Rec. 2049/2013) que declara que no se puede entender ejecutada una sentencia por el mero hecho de que la Administración subsane los defectos formales que dieron lugar a la nulidad, porque no cabe la convalidación de actos nulos lo que exige a la Administración iniciar, de nuevo, el procedimiento administrativo ${ }^{32}$.

De ahí que la ley, lejos de recurrir a una mera previsión de carácter programático, sancione la nulidad de pleno derecho de «los actos y disposiciones contrarios a los pronunciamientos de las sentencias, que se dicten con la finalidad de eludir su cumplimiento» (art. 103.4), supuesto que viene a sumarse a la enumeración que el art.

32 De acuerdo con la sentencia cumple formular las siguientes consideraciones:

1) De ningún modo cabe aceptar que la ejecución de la sentencia pueda tener lugar simplemente mediante la mera subsanación de los defectos formales de que adolecen las resoluciones administrativas impugnadas y anuladas en la instancia, tal y como se ha pretendido, por medio de la consiguiente convalidación «a posteriori».

... sostiene el recurso de reposición que ese defecto no es de nulidad, sino de anulabilidad susceptible de ser subsanado ... argumento que no puede acoger esta sala, pues en este momento procesal no sólo no se pueden traer cuestiones nuevas no esgrimidas por las partes ni analizadas en la sentencia, sino que tampoco se puede insistir en ellas ni rebatir los razonamientos jurídicos de la resolución judicial con otros fuera del cauce legal (los recursos procedentes).

2) Pero es que, en cualquier caso, y más allá de ello, la convalidación de los actos anulables constituye una técnica específica dispuesta por nuestro ordenamiento jurídico para la conservación de los actos que adolecen de este defecto (art. 67 LRJPAC), que permite sanar en efecto tales actos anulables (no así los nulos de pleno derecho); pero, ello, siempre y cuando la Administración acuda a dicha técnica al margen del proceso y la cuestión no haya sido objeto de pronunciamiento judicial.

En otros términos, la convalidación afecta solo a resoluciones administrativas cuya invalidez aún no ha sido declarada; o, si prefiere también, no se puede sanar un defecto invalidante una vez que la invalidez se ha declarado. Declarada la invalidez, por lo demás, resulta incluso indiferente que la infracción del ordenamiento jurídico determinante de la anulación de un acto fuera causa de nulidad de pleno derecho o anulabilidad, a los efectos de aplicar la técnica de la convalidación; porque sencillamente no ha lugar a la aplicación de convalidación en ninguno de los dos casos.

3) Por tanto, si esto es así con carácter general, menos aún cabe recurrir a la convalidación en trance de ejecución de sentencia: la anulabilidad de los actos administrativos que es la consecuencia anudada a la mayor parte de los actos administrativos inválidos, porque la nulidad de pleno derecho es la excepción (arts. 62 y 63 de la Ley 30/1992 carecería, además, de toda relevancia real si no fuera así tratándose de defectos formales, porque la Administración se limitaría entonces a realizar «a posteriori» lo que no hizo en el momento debido ; y escaso sería por tanto su estímulo para observar con el esmero debido las exigencias formales dispuestas por el ordenamiento jurídico.

Lo que procede es cumplir el fallo, lo que exige el cese del uso y la demolición de la gasolinera, salvo que, por su cauce, plazo, legitimación y forma, se promueva un incidente de inejecución ..., por estar en juego el derecho fundamental a que las sentencias se cumplan (STSS de 27.07.01, 29.10.92 y 16.07.91, así como auto de dicha Sala de 26.11.09), circunstancia que no evitaría un posible pronunciamiento favorable a la inejecutabilidad que, por las razones indicadas, no se puede producir en este momento, de manera que el recurso debe ser desestimado.

Esto es, por expresarlo de manera sucinta, procede ahora reconstruir el procedimiento entero, y volver a iniciar éste por tanto desde el primero de los trámites que resultan exigibles para la obtención de los títulos jurídicos habilitantes para el desarrollo de la actividad pretendida ... 
47 de la Ley de Procedimiento Administrativo Común realiza de los motivos por los que procede declarar la nulidad de pleno derecho ${ }^{33}$.

No obstante hay que hacer notar dos cosas respecto de dicha garantía: en primer lugar, que existe una limitación para que dicho artículo opere ya que resulta preciso que se haya dictado un nuevo acto o disposición pues si se trata de un cumplimiento torcido de la ejecución dicha garantía prácticamente se desvanece; de otro, y en segundo lugar, que inclusive en el supuesto de que se hubiesen dictado actos o disposiciones, ha de tenerse plenamente presente el requisito añadido que se establece para dicha declaración de nulidad consistente en un requisito teleológico sumamente problemático de apreciar, a saber: que los mismos hayan sido adoptados "con la finalidad de eludir su cumplimiento" ".

A pesar de la redacción legal que parece involucrar un elemento volitivo en la actuación administrativa dirigido a eludir el cumplimiento del fallo, y no compartiendo en este punto la opinión de GONZALEZ PEREZ ${ }^{35}$, desde mi punto de vista es el contenido material del acto el factor determinante de la infracción de nulidad, independientemente de que concurriese o no tal finalidad bien es cierto que los tribunales han exigido ese elemento, que se califica como supuesto calificado de desviación de poder, para producir el efecto anulatorio (STS de 1 de marzo de 2006, RJ 2070).

Esta última circunstancia, ratificada jurisprudencialmente, es determinante de que, por un lado, haya de admitirse que, en aquellos supuestos en que no pueda acreditarse dicha circunstancia o la misma simplemente no concurra, no será posible declarar la nulidad de los actos o disposiciones dictados que amparan lo realizado y declarado no ajustado a derecho por órganos jurisdiccionales. Pero, por otra, a que

33 Un detallado análisis de los requisitos precisos para dicha declaración de nulidad puede verse en GALAN GALAN, A., "Los poderes del Juez en la ejecución de sentencias: reacción frente a los actos de la Administración o del legislador que tengan como finalidad eludir su cumplimiento", en el volumen colectivo La ejecución de sentencias contencioso-administrativas (coord. SANCHEZ LAMELAS, A.), Thompson-Aranzadi, Navarra, 2006, págs.. 133 y ss.

34 El control de la discrecionalidad del órgano administrativo es aquí esencial para que una modificación no responda a intereses espurios no acordes con el principio del interés general. La STSJ Madrid 1358/2009, de 20 de noviembre, nos precisa cuáles son las exigencias del principio del interés general: "la racionalidad de las nuevas decisiones urbanísticas, la correcta valoración de las situaciones fácticas, la coherencia de la utilización del suelo con las necesidades objetivas de la comunidad, la adecuada ordenación territorial y el correcto ajuste a las finalidades perseguidas, y como afirman las SSTS de 3/enero y 26/ marzo/1996, el control jurisdiccional de las facultades discrecionales de la Administración debe encaminarse a examinar "la existencia de un desacomodamiento a lo legal o reglamentariamente dispuesto, una desviación de poder o una arbitrariedad o irracionalidad en la solución propuesta por el plan, ya que en lo demás goza de una entera libertad para elegir la forma en que el territorio ha de quedar ordenado..."

GONZÁLEZ PÉREZ, J., Comentarios a la Ley de la Jurisdicción Contencioso-Administrativa (Ley 29/1998, de 13 de julio), Madrid, 1998, pág. 1773. 
deban aquilatarse aquellos casos en que tales circunstancias se producen $\mathrm{y}^{36}$, con ello, la eventualidad, también establecida en nuestro ordenamiento jurisdiccional, de alegar la imposibilidad legal de ejecución de la sentencia en los términos, y con arreglo al procedimiento previsto, en el artículo 105.2 LJCA. Que conlleva asimismo, y conviene señalarlo, la preceptiva indemnización ${ }^{37}$.

Precisamente, y por la eventual concurrencia de dichas circunstancias, es de hacer notar que, como ha puesto de manifiesto SANGHEZ GOYANES ${ }^{38}$, la aplicación del artículo 103.4 LJCA requiere una adecuada ponderación de los intereses que se encuentran en juego, puesto que expresamente advierte el citado autor de que existe el evidente riesgo, tanto de una jurisprudencia muy restrictiva que convierta en vacío dicho artículo, permitiendo en todo caso y sin restricción la posibilidad de la inejecución de la sentencia y su conversión en una indemnización sustitutoria, ante la aprobación de una nueva norma o acto administrativo, como una interpretación extensiva del mismo que entorpezca decisivamente la consecución de los intereses públicos impidiendo cualquier nuevo acto o norma que incida sobre el mismo supuesto.

Esto conduce ineludiblemente a que hayan de determinarse en qué casos, y con qué requisitos, ello es posible A este respecto, y para establecer aquellos supuestos en que sí sería posible, a juicio de SANCHEZ GOYANES, es preciso operar de forma

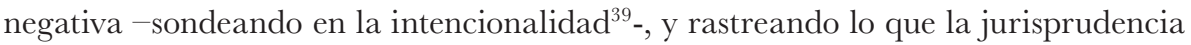
del Tribunal Supremo ha establecido a este respecto.

36 Especial incidencia tienen estos supuestos en materia urbanística y es que la aprobación de un nuevo planeamiento no es suficiente razón, por ella misma, para tener por legalizada una obra ejecutada en contra del ordenamiento vigente al tiempo de su construcción. Asimismo, es de señalar que el incidente previsto en el artículo 105.2 LJCA tampoco tiene por objeto declarar legalizada la obra en cuestión, sino que la auténtica finalidad de dicho incidente queda limitada a controlar si resulta ajustada a derecho, y por tanto no intenta eludir el cumplimiento efectivo del fallo, la imposibilidad material o legal de ejecutar la sentencia que la Administración que debía hacerlo efectivo alega para dejar sin efecto el mismo.

37 Como es conocido la regla general es que la Administración autora del acto anulado por la sentencia inejecutable es la que debe indemnizar. Sin embargo, cuando existe un particular que se beneficia de la imposibilidad, la regla general puede ceder en determinadas circunstancias. En la STS de 12 de febrero de 2004 se condenó al Ayuntamiento y al promotor beneficiario de la inejecución como responsables mancomunados del coste de la indemnización sustitutoria. El Ayuntamiento reclamó que se imputara la responsabilidad exclusivamente al promotor, por entender que era el único beneficiado, por las ganancias derivadas de las construcciones. Sin embargo, tal y como argumenta el Tribunal, el Ayuntamiento también se beneficia de la inejecución, porque la ejecución hubiese implicado indemnización derivada de la responsabilidad por anulación del acto administrativo que dictó.

38 SANCHEZ GOYANES, E., "Problemática en la ejecución de sentencias urbanísticas", Revista de Estudios Locales, CUNAL, n $178,2015$.

39 Bien es cierto que JIMÉNEZ BUESO, A., "Modificaciones de planeamiento y ejecución fraudulenta de sentencias en materia de urbanismo", Práctica Urbanística, no 105, Ed. La Ley, Madrid, Junio 2011 , pp. 23-24, sostiene que resulta inadecuado mantener la nulidad del artículo 103.4 LJCA sobre un elemento intencional o subjetivo -la intención de eludir la ejecución de la sentencia- y que el fraude sólo 
Completando estos supuestos, de carácter jurídico en su esencia, que se materializan mediante la emisión de actos o disposiciones ${ }^{40}$, el art. 108.2 prevé respecto de las sentencias condenatorias de contenido no pecuniario, y por tanto relativas a una ejecución material, la reposición judicial de la actividad administrativa que contraviene el fallo judicial, con determinación en favor del interesado de los daños y perjuicios derivados del incumplimiento constatado.

Cabe finalizar este apartado aludiendo a que, tanto respecto de la disposición general del art. 103.4, como para la específica del art. 108.2, el cauce procedimental no va a ser otro que el incidental previsto en el art. 109 LJCA.

debería apreciarse por los tribunales sobre la base de criterios estrictamente objetivos, tales como la falta de motivación del instrumento, la inobservancia de los requisitos exigidos por la legislación sectorial aplicable o el incumplimiento del principio de equidistribución. Este mismo autor se hace eco de los supuestos citados por SANCHEZ GOYANES y que apunta se recogen en la Sentencia del Tribunal Supremo de 23 de diciembre de 2010 (Recurso de Casación núm. 2970/2006).

40 Mención aparte merecen aquellas normas, con rango formal de Ley, que amparan la inejecución de sentencias judiciales. Al respecto cabe reseñar aquí la doctrina establecida por el Tribunal Europeo de Derechos Humanos que, en sentencia de 24 de abril de 2004 (caso Gorraiz Lizárraga y otros vs. España), que estimó, a propósito de la STC que no existió vulneración, pero recordó su doctrina sobre las intervenciones del Estado mediante la vía legislativa para reorientar una causa que le era desfavorable (casos Stran y Stratis Andreadis vs. Grècia; Papageorgiou vs. Grecia). La propia STC 73/00 había hecho referencia a la jurisprudencia del TEDH en relación con aquellos supuestos en los que se ha dictado una Ley cuyo efecto directo es el de influir en el desenlace judicial de un litigio en el cual el Estado es parte. Y ciertamente, en la STEDH de 23 de octubre de 1997, asunto National and Provincial Buiding Society y otras c. Reino Unido, se había dicho que el art. 6.1 del Convenio de Roma de 1950 no puede interpretarse en el sentido de que es incompatible con toda injerencia de los poderes públicos en un proceso judicial pendiente. Pero en relación con otros supuestos en los que se dictó una Ley cuyo objeto era impedir la ejecución de un fallo que condenaba al Estado al pago de una indemnización, el mencionado Tribunal, aun reconociendo que la finalidad de la ley era legítima, tras considerar las concretas circunstancias del proceso ha declarado que resulta contradictoria tanto con el principio de "preeminencia del Derecho" consagrado en el art. 3 del Estatuto del Consejo de Europa como con la noción de "proceso justo" del art. 6.1 del Convenio de Roma de 1950 "cualquier injerencia del poder legislativo en la administración de justicia con la finalidad de influir en el desarrollo judicial de un litigio", por estimar que en tales supuestos el Estado había intervenido mediante la Ley de forma decisiva para orientar en su favor la solución judicial del caso (Sentencia de 9 diciembre de 1994, asunto Stran y Stratis Andreatis c. Grecia, párrafos 42 a 50, doctrina reiterada en la Sentencia de 22 de octubre de 1997, asunto Papageorgiu c. Grecia).

En el ámbito interno, la Sentencia del Tribunal Constitucional de 28 de mayo de 2014 -puede verse, asimismo, a STC 92/2013- declara incompatible con la reserva estatal en materia de legislación procesal que el legislador autonómico establezca una causa de suspensión o aplazamiento de la ejecución de las Sentencias que han de ejecutarse mediante el derribo de edificaciones, sobre todo cuando el precepto legal no condiciona la efectividad de la demolición judicialmente acordada al transcurso de determinados plazos para resolver el expediente de responsabilidad patrimonial, sino a su efectiva resolución y al pago de la indemnización acordada, de suerte que la ejecución de la Sentencia acaba quedando fuera del control judicial, único competente para hacer ejecutar lo juzgado a tenor de lo dispuesto en el art. 117.3 CE, que resulta igualmente vulnerado. Asimismo, puede consultarse la Sentencia del Tribunal Constitucional 254/2015, de 30 de noviembre. 


\section{EJEGUGIÓN DE GONDENAS PEGUNIARIAS}

La Ley de 1998 optó, a la vista de la experiencia acontecida con la legislación de 1956 muy austera en la materia (artículo 108), por una regulación más pormenorizada, estableciéndose en la norma dos presupuestos de inevitable concurrencia, a saber: la liquidez y la firmeza a las que ya nos hemos referido.

En esta materia, relativa al régimen de ejecución de las condenas pecuniarias, conviene advertir de que, como es conocido en la ejecución de sentencias que condenan al pago de una cantidad líquida a la Administración, la misma se ve dificultada por dos notas: una primera consistente en un privilegio tradicional, inherente al estatuto constitucional de la Administración pública y de carácter expreso previsto en distintas normas jurídicas, consistente en la prohibición, con carácter general, de despachar mandamientos de embargo contra la bienes y derechos de la hacienda pública; la segunda, de carácter fáctico, que no es otro que la propia solvencia de la Administración que aunque no de forma expresa subyace en la regulación de la ejecución de las condenas pecuniarias contra la Administración al prohibir declarar inejecutables las sentencias de tal naturaleza, admitiéndose únicamente la flexibilización del régimen de cumplimiento en los términos que seguidamente serán objeto de análisis.

\section{La medidas tendentes a la agilización de la ejecución de las condenas pecuniarias}

Puede decirse que el conjunto de medidas previstas para la ejecución de condenas pecuniarias tiene dos objetivos fundamentales: de un lado, agilizar el pago de la Administración de la cantidad líquida debida; y, de otro, compensar a la parte favorecida por la sentencia frente a los eventuales retrasos no justificados de la Administración por las contradicciones que puedan producirse entre la legalidad administrativa y la presupuestaria que fueron resueltas por el Tribunal Constitucional en forma temprana dejando establecido que "los privilegios que protegen a la Administración no la sitúan fuera del ordenamiento jurídico” (SSTC 32/1982 y 67/1984).

En este sentido, dicha regulación contempla diversas medidas conducentes a obtener dichos resultados. Demos cuenta de las mismas.

a) Carácter ampliable de los créditos presupuestarios a fin de ejecutar el pago (art. 106.1).

El pago de las cantidades debe ajustarse a lo establecido en la legislación presupuestaria lo que tiene como directa consecuencia que estos pagos no se pueden realizar si previamente no hay consignación presupuestaria y, como está establecido 
normativamente, esta decisión corresponde en último extremo a la Administración condenada ${ }^{41}$.

A fin de salvar dicho inconveniente la ley establece el carácter «ampliable» del crédito presupuestario con cargo al cual deberá acordarse el pago, estableciendo un plazo de tres meses, con carácter preclusivo, para la «conclusión»-que no para la «iniciación» como se contemplaba en el antiguo art. 108 de la LJCA 1956- del procedimiento de modificación presupuestaria a contar desde la notificación de la resolución judicial (artículo 23.3 Ley General Presupuestaria).

b) Devengo de intereses de demora (art. 106.2 y 3 ).

El devengo de éstos tendrá lugar ministerio legis desde la fecha de notificación de la sentencia dictada en primera o única instancia y «hasta que sea totalmente ejecutada» lo que tiene, como consecuencia directa, que el devengo queda al margen de cualquier apreciación judicial, a no ser en el extremo relativo al incremento del tipo aplicable de apreciarse falta de diligencia en el cumplimiento (art. 106.3) ${ }^{42}$.

Ahora bien, si los intereses establecidos en el apartado 2 se establecen de forma automática lo cierto es que la aplicación del apartado 3, dada la configuración legal efectuada, presenta mayores dificultades de orden probatorio por cuanto se desplaza

$41 \quad$ En el ámbito local, el artículo 173 del Real Decreto Legislativo 2/2004, de 5 de marzo, por el que se aprueba el texto refundido de la Ley Reguladora de las Haciendas Locales (TRLRHL) establece en su apartado 1 que:

"1. Las obligaciones de pago sólo serán exigibles de la hacienda local cuando resulten de la ejecución de sus respectivos presupuestos, con los límites señalados en el artículo anterior, o de sentencia judicial firme"

Y en los apartados 3 y 4 del citado artículo se contemplan las siguientes previsiones:

"3. El cumplimiento de las resoluciones judiciales que determinen obligaciones a cargo de las entidades locales o de sus organismos autónomos corresponderá exclusivamente a aquéllas, sin perjuicio de las facultades de suspensión o inejecución de sentencias previstas en las leyes.

4. La Autoridad administrativa encargada de la ejecución acordará el pago en la forma y con los límites del respectivo presupuesto. Si para el pago fuere necesario un crédito extraordinario o un suplemento de crédito, deberá solicitarse del Pleno

42 Como explicita el ATS 6237/2016, de 24 de junio: TERCERO.- Habida cuenta del tiempo transcurrido desde que se dictó el referido Auto de ejecución de 29 de julio de 2015 no procede acceder a lo solicitado por el representante de la Administración. En dicho Auto se aprobaban cantidades determinadas para la ejecución de la Sentencia de 12 de julio de 2013 y el procedimiento de cálculo de los intereses, por lo que el pago de las cantidades debidas como capital e intereses no requería ningún trámite especial por parte de la Administración que haga que este Tribunal deba requerir información alguna sobre lo que constituye una manifiesta falta de diligencia por parte de la Administración en ejecutar las resoluciones firmes de esta Sala. En consecuencia, se estima la solicitud formulada por Endesa y se requiere a la Administración a la inmediata ejecución de la Sentencia citada en los términos resueltos en el fallo y fundamento de derecho segundo del Auto de 29 de julio de 2015, abonando a la sociedad recurrente la cantidad estipulada como capital con los correspondientes intereses calculados en la forma que se indicaba. Estos intereses quedarán incrementados en dos puntos a partir de la fecha de notificación de este Auto. 
al que insta la ejecución la carga de la prueba de la eventual concurrencia de negligencia administrativa en la ejecución, debiendo el juez ejecutor recabar el parecer de la Administración sobre las circunstancias que han provocado la dilación en el pago. En efecto, con la intención de que no se produzca demora alguna la ley prevé el incremento en dos puntos de los intereses moratorios si instándose la ejecución forzosa -lo que podrá tener lugar transcurridos tres meses desde la «comunicación de la sentencia firme» al «órgano que deba cumplirla»-, el juez apreciase que persiste una «falta de diligencia en el cumplimiento».

De esta forma, y desde nuestro punto de vista, los requisitos exigibles para que se produzca el devengo de los intereses incrementados en dos puntos previstos en el apartado tercero requiere de la concurrencia simultánea de dos elementos: un elemento de carácter objetivo consistente en el transcurso del plazo de cumplimiento voluntario; y otro, ahora de carácter subjetivo, relativo a la existencia de una conducta de negligencia, desidia o resistencia por parte de la Administración al cumplimiento de la sentencia que ha de ser apreciada judicialmente.

En cualquier caso, y en relación a este punto, parece claro que se otorga un criterio más favorable a la Administración que a los particulares, de acuerdo con el régimen previsto para éstos en el artículo 576 LECiv que contempla los dos puntos adicionales desde el dies a quo de notificación de la sentencia (STS 10 de julio de 1992, RJ 6324), lo que sin embargo no se ha considerado contrario al principio de igualdad por la STG 206/1993, de 22 de junio que justificó, a nuestro parecer sin suficiente fundamento, ese especial régimen, no en la posición preeminente de la Administración, sino en los principios de legalidad y contabilidad pública que condicionan su actuación y obstaculizan su cumplimiento ágil.

c) Compensación de créditos.

De acuerdo con lo establecido en el art. 106.6, que establece que ésta puede ser hecha valer por «cualquiera de las partes» procesales, se prevé la compensación de créditos. Su invocación por el ejecutante supone, como en otros supuestos ya referidos, su articulación por vía de incidente.

Por tanto, y en lo referido a este último supuesto, han de concurrir dos requisitos: el primero, de carácter sustantivo, consistente en que concurran los requisitos generales de la compensación [arts. 1195 y siguientes del Código Civil y 67 y 68 del Reglamento General de Recaudación]; y otro, de carácter adjetivo, consistente en que no haya sido objeto de debate en el proceso declarativo pues, si habiéndose debatido su procedencia en el declarativo no fue acogida por la sentencia, la compensación podría quedar afectada por la cosa juzgada. Distinto seria el supuesto, que no se vería afectado por el principio de preclusión, de que no hubiese sido invocada por haber sobrevenido la concurrencia de sus requisitos legales con posterioridad. 


\section{Los límites a la ejecución de condenas pecuniarias}

Como ya fue referido más arriba el sistema procesal ejecutivo de las condenas pecuniarias viene condicionado por dos consideraciones previas que, sin embargo, están estrechamente relacionadas entre sí: de un lado, la solvencia de la Administración que no la inexistencia de crédito presupuestario como ya hemos referido; de otro, la prohibición legal de embargabilidad de los bienes y derechos de la Hacienda pública.

En relación al primero el art. 106.4 prevé modalidades alternativas de ejecución cuando el cumplimiento de la sentencia pudiera producir a la Administración un «trastorno grave a su Hacienda», manifestación ésta que deberá acompañarse de una «propuesta razonada» que será sometida a consideración de las partes, debiendo resolver el juez en último término sobre «el modo de ejecutar la sentencia en la forma que sea menos gravosa para aquélla».

Presenta, en esta materia, especial relevancia la determinación de los extremos o factores sobre los que puede versar la propuesta de la Administración. Y al respecto es preciso advertir de dos extremos: en primer lugar, que la flexibilización del régimen de cumplimiento nunca puede suponer la transformación de la prestación debida, no siendo admisibles prestaciones de contenido no pecuniario lo que se ha visto ratificado por la jurisprudencia de nuestros tribunales (STSJ de Madrid de 9 de junio de 2016 (JUR 185389); y, en segundo lugar, que la norma exige una propuesta que sea «razonada», lo que ha de traducirse en que la Administración ha de individualizar los hechos fácticos que justifican el grave trastorno que para la hacienda pública supondría el cumplimiento en sus propios términos del fallo judicial lo que precisará ulteriormente de que el órgano jurisdiccional se pronuncie sobre la dificultad en el cumplimiento hecha valer por la Administración, evitando así que la mera invocación de unos supuestos motivos, sin base documental alguna y acreditación de la excepcionalidad, puedan suponer un obstáculo a la plena efectividad del fallo judicial o a que su cumplimiento efectivo se demore en exceso (SSTSJ de Madrid de 19 de marzo de 2014, JUR 197691 y de 20 de octubre de 2015, JUR 308114).

La determinación judicial de la modalidad de cumplimiento es, de nuevo, una cuestión incidental que como tal deberá acordarse previa audiencia de las partes en plazo común que no excederá de veinte días (art. 109.2). De esta forma, entre las modalidades alternativas de cumplimiento del fallo adquieren importancia singular las propuestas de aplazamiento o fraccionamiento del pago. En todo caso, el órgano jurisdiccional puede acoger propuestas formuladas por las propias partes procesales e, inclusive, integrar elementos procedentes de las propuestas formuladas por unas y otras, de forma tal que la reducción de los efectos gravosos que para la hacienda 
pública podría tener el cumplimiento inmediato del fallo no se traduzca en una carga en exceso gravosa para la otra parte.

Es preciso referirnos en este punto a las previsiones establecidas en la Ley Orgánica 6/2015, de 12 de junio, de modificación de la Ley Orgánica 2/2012, de 27 de abril, de Estabilidad Presupuestaria y Sostenibilidad Financiera, y en la que la Disposición Adicional Primera, que regula la "Financiación de la ejecución de sentencias firmes por parte de las Entidades locales", permite acudir a los Fondos de Ordenación e Impulso Económico que conforman el Fondo de financiación a entidades locales, regulado mediante Real Decreto-Ley 17/2014, de 26 de diciembre, de medidas de sostenibilidad financiera de las comunidades autónomas y entidades locales y otras de carácter económico lo que aporta novedades en este concreto punto.

El objetivo de este Fondo es dotar a las entidades locales de un mecanismo de financiación adicional y extraordinario de apoyo a la liquidez desde el Estado, en cumplimiento de lo dispuesto en la Disposición Adicional Primera de la LOEPSF, que regula los mecanismos adicionales de financiación para Comunidades Autónomas y Corporaciones Locales ${ }^{43}$ y todo ello para evitar, como ya ha acontecido, que la ejecución de sentencias judiciales pueda poner en riesgo la sostenibilidad financiera de la Hacienda Pública lo que se ha considerado motivo suficiente para acceder al fraccionamiento y aplazamiento del pago (STSJ de Murcia de 10 de noviembre de 2016, RJCA 2017, 108).

43 Prevé dicha disposición que:

1. En los supuestos de ejecución de sentencias firmes de los Tribunales de Justicia, las entidades locales podrán incluir las necesidades financieras que sean precisas para dar cumplimiento a las obligaciones que se deriven de las mismas, en los compartimentos Fondo de Ordenación o Fondo de Impulso Económico, del Fondo de Financiación a Entidades locales, si se encuentran en las situaciones descritas en los artículos 39 o 50 del Real Decreto-ley 17/2014, de 26 de diciembre, de medidas de sostenibilidad financiera de las Comunidades Autónomas y Entidades locales y otras de carácter económico, siempre que se justifique la existencia de graves desfases de tesorería como consecuencia de aquella ejecución. A estos efectos se entenderá por entidad local la Administración General de la misma, y el resto de entidades, organismos y entes dependientes de aquélla, incluidos en el sector Administraciones Públicas, subsector Corporaciones Locales, de acuerdo con la definición y delimitación del Sistema Europeo de Cuentas Nacionales y Regionales de la Unión Europea.

2. Las necesidades financieras citadas en el apartado anterior se incluirán en los compartimentos del Fondo de Financiación a Entidades Locales en los términos que acuerde la Comisión Delegada del Gobierno para Asuntos Económicos, y, en su caso, deberán recogerse en los planes de ajuste que acompañen a las solicitudes de adhesión.

3. Las entidades locales que se acojan a la medida regulada en esta disposición están obligadas a dotar en el proyecto de presupuesto general del ejercicio 2016 el Fondo de Contingencia de ejecución presupuestaria por una cuantía equivalente al 1 por ciento de sus gastos no financieros con el fin de atender posibles obligaciones de pago derivadas de futuras sentencias firmes que dicten los Tribunales de Justicia o necesidades imprevistas e inaplazables. El cumplimiento de este requisito es condición necesaria para la adhesión a los compartimentos del Fondo de Financiación a Entidades Locales. 
De otro lado, y como ya mencionáramos, es preciso abordar, asimismo, el privilegio tradicional contenido en la Ley General Presupuestaria, y otras normas, relativo a la inembargabilidad de los bienes y derechos de la Hacienda Pública y la problemática que este comporta en relación al cumplimiento de lo dispuesto en el fallo de sentencias que contienen una condena pecuniaria para la Administración.

Cabe comenzar aludiendo a que la prohibición de embargabilidad de los bienes de dominio público y comunales, que también está expresamente establecida constitucionalmente (art. 132.1 de la Constitución), requiere de algunas matizaciones. En efecto, ya la Sentencia núm. 166/1998 del Tribunal Constitucional abordó la desaparición de los seculares privilegios de autoejecución e inembargabilidad de los bienes y derechos de las Administraciones Públicas, que implicaban en la práctica (art. 106 del antiguo Reglamento General de Recaudación aprobado por Real Decreto 1684/1990) la calificación de éstas como entidades «no apremiables»e «inembargables» ${ }^{44}$. Y en el mismo sentido se pronunció el Tribunal Constitucional en su Sentencia 228/1998, de 1 de diciembre (Fundamento Jurídico 3) ${ }^{45}$.

Bien es cierto que la sentencia 166/1998, no abordó un problema de enorme relevancia ${ }^{46}$, a saber: la determinación concreta de los bienes y derechos embargables.

$44 \quad$ En efecto, esta Sentencia supuso la desaparición de nuestro ordenamiento jurídico tanto del concepto de entidades «no apremiables» como del privilegio de la inembargabilidad absoluta de los bienes y derechos de éstas: «... el privilegio de inembargabilidad de los "bienes en general" que consagra el art. 154.2 de la Ley de Haciendas Locales, en la medida en que comprende no sólo los bienes demaniales y comunales sino también los bienes patrimoniales pertenecientes a las entidades locales que no se hallan materialmente afectados a un uso o servicio público, no resulta conforme con el derecho a la tutela judicial efectiva que el art. 24.1 de la Constitución garantiza a todos, en su vertiente de derecho subjetivo a la ejecución de las resoluciones judiciales firmes» .

La doctrina constitucional y la jurisprudencia del Tribunal Supremo, consecuencia de aquélla, determinaron asimismo la desaparición de nuestro ordenamiento jurídico de la obsoleta terminología derivada del art. 106.3 del antiguo Reglamento General de Recaudación, aprobado por RD 1684/1990, de 20 de diciembre, en el que se hacía referencia a «Entidades públicas que por Ley no puedan ser objeto de apremio»; así, el art. 70.4 del RD 939/2005, de 29 de julio, por el que se aprueba el Reglamento General de Recaudación, hace referencia a la posibilidad de proceder al embargo de los bienes de las referidas entidades.

45 No obstante, algunas leyes de las Comunidades Autónomas, mantienen en vigor preceptos que siguen haciendo referencia a la inembargabilidad de la totalidad de los bienes y derechos que integran el patrimonio de dichas administraciones públicas. Muy significativo al respecto es el art. 27.2 del Decreto legislativo 1/2010, de 2 de marzo, por el que se aprueba el Texto Refundido de la Ley de Hacienda Pública de Andalucía, esto es, aprobado con posterioridad a la modificación de la normativa básica estatal sobre el patrimonio de las administraciones públicas, y en el que, en franca contradicción con lo establecido en aquélla, se declara que los valores, los créditos y demás recursos financieros de la Tesorería General de la Junta de Andalucía se consideraran siempre afectados materialmente a un servicio público o a una función pública y, por tanto, inembargables.

46 Puede verse, en torno a este punto, SÁNCHEZ ONDAL, J.J., "Las Entidades Locales como sujetos activos y pasivos de la ejecución de créditos". http://www.elderecho.com/tribuna/administrativo/ Entidades-Locales-activos-ejecucion-creditos_11_183805008.html. 04.10.2010 y el detallado estudio de 
e, inclusive, complicó considerablemente dicha determinación cuando en su Fundamento Jurídico Noveno se pronunció inequívocamente sobre la inembargabilidad de los fondos públicos de manera contundente e indubitada ${ }^{47}$.

De esta forma, dicha declaración de inembargabilidad de los fondos, junto con la dificultad de concreción de los bienes patrimoniales de las administraciones públicas deudoras susceptibles de ser embargados, se configuraron como los dos grandes obstáculos con los que habrían de enfrentarse los órganos jurisdiccionales para llevar a buen puerto la ejecución de sentencias judiciales que contengan la condena a la Administración por una cantidad liquida. Vayamos por partes.

En primer lugar, y en lo referido a la inembargabilidad de los bienes y derechos de las Administraciones públicas, y muy en especial de las entidades locales, es preciso señalar que no ha sido pacífica, y más bien ha dado lugar a posturas contradictorias de los propios órganos jurisdiccionales sobre todo en lo que se refiere a si han de entenderse o no incluidos los fondos públicos, dicha cuestión. En este sentido, cierta jurisprudencia menor (por todos, el Auto de la A.P de Teruel 76/2004 y el más reciente de la A.P. de Granada 106/2012), optando por una interpretación de nuestro ordenamiento jurídico más favorable a los intereses de las administraciones públicas, calificaría como inembargables los fondos depositados en cuentas titularidad de éstas. De contrario, el TS en varias sentencias - STS de 29 de enero de 1999 y STS de 9 y 18 de febrero de 2005- considera que el dinero de las Administraciones públicas es embargable ${ }^{48}$.

IBAÑEZ LÓPEZ, F. Y IBAÑEZ LOZANO, F., "La superación de la doctrina constitucional contenida en la Sentencia 166/1998, de 15 de julio, por lo que se refiere a la inembargabilidad del dinero y ciertos bienes patrimoniales de las administraciones públicas", El Consultor de los Ayuntamientos y los fuzgados, No 4, 2016 de cuyo trabajo se toman algunas consideraciones y referencias jurisprudenciales.

${ }_{47}$ Y es que, ambas SSTC de 1998, justifican la inembargabilidad de dichos fondos al señalar que: «Esta alegación (la relativa a la inembargabilidad de los bienes y fondos públicos alegada por el Abogado del Estado) ciertamente ha de compartirse con lo que respecta a «los derechos, fondos y valores» de la Hacienda local, a los que se refiere el precepto legal antes mencionado. Estos, en efecto, son los «recursos financieros» de la Entidad local, ya se trate de «dinero, valores o créditos» resultantes de «operaciones tanto presupuestarias como extrapresupuestaria», que constituyen la Tesorería de dicha Entidad (art. 175.1 LHL). Y dado que tales recursos están preordenados en los presupuestos de la Entidad a concretos fines de interés general, es evidente que requieren una especial protección legal, tanto por su origen en lo que respecta a los ingresos de Derecho público - la contribución de todos al sostenimiento de los gastos públicos (art. 31.1 CE) como por el destino al que han sido asignados por los representantes de la soberanía popular».

${ }_{48}$ El Fundamento Jurídico Quinto de la sentencia de 29 de enero de 1999 establece lo siguiente:

"QUINTO.- La argumentación, además, contenida en la sentencia recurrida respecto de la "inembargabilidad de los bienes, derechos, valores y fondos públicos, (salvando el art. 132.1 de la Constitución )" como obstáculo al reconocimiento de la posibilidad de utilización del procedimiento de apremio contra las cuentas corrientes del Institut Català del Sòl para la cobranza de los Impuestos Municipales al principio señalados, debe considerarse, asimismo, errónea, tan pronto se tenga en cuenta que, con arreglo a reiterada doctrina constitucional, "el privilegio de la inembargabilidad solo alcanza a los bienes que estén destinados 
Bien es cierto que la problemática no quedaba ahí y la discordancia entre las previsiones establecidas en la legislación hacendaria local y las que se contemplan en la legislación patrimonial han mantenido algunas dudas sobre la cuestión ${ }^{49}$. Ello ha provocado nuevos pronunciamientos jurisdiccionales en que, ha de advertirse que aún no de forma definitiva, se ha zanjado la cuestión. De esta forma, y con arreglo a éstos, se confirma que el dinero no forma parte de los bienes y derechos inembargables $^{50}$. Y doctrinalmente, asimismo, se mantienen visiones matizadas sobre este

a la realización de actos "iure imperii", pero no a aquellos destinados a la realización de actividades "iure gestionis", porque una interpretación de las normas que condujera a mantener la imposibilidad absoluta de ejecución de las Administraciones públicas debía considerarse vulneradora del art. 24.1 de la Constitución - STC / 1992, de lo de Julio -, y más aún cuando la Norma Fundamental - art. 132.1- solo refiere la inembargabilidad a los bienes de dominio público y a los comunales. Más recientemente, el mismo Supremo Intérprete de la Constitución admite la susceptibilidad de embargo de "bienes patrimoniales no afectados a un uso o servicio público" - SS.T.C. 166/1998, y $211 / 1998$, de 27 de Octubre -, hasta el extremo de considerar inconstitucional en la primera de las dos sentencias acabadas de mencionar el último inciso, "bienes en general", del ap. 2 del art. 154 de la Ley de Haciendas Locales, precisamente por la amplitud y generalidad de esta expresión y por no incluir la excepción al principio de inembargabilidad que dichos bienes en las expresadas condicionen significaban".

49 En efecto, el artículo 57.2 de la Ley 50/1998, de 30 de diciembre, de medidas fiscales, administrativas y del orden social, dio una nueva redacción al art. 154.2 LHL, que es la que se ha mantenido en el vigente art. 173.2 del Texto Refundido de la LRHL, aprobado por RD Legislativo 2/2004, de 4 de marzo, según el cual: «Los tribunales, jueces y autoridades administrativas no podrán despachar mandamientos de ejecución ni dictar providencias de embargo contra los derechos, fondos, valores y bienes de la hacienda local ni exigir fianzas, depósitos y cauciones a las entidades locales, excepto cuando se trate de bienes patrimoniales no afectados a un uso o servicio público".

Por su parte, y sin embargo, la Ley 33/2003, de 3 de noviembre, de Patrimonio de las Administraciones Públicas (LPAP), establece en su art. 30.3, lo siguiente: «Ningún Tr3ibunal ni autoridad administrativa podrá dictar providencia de embargo ni despachar mandamiento de ejecución contra los bienes y derechos patrimoniales cuando se encuentren materialmente afectados a un servicio público o a una función pública, cuando sus rendimientos o el producto de su enajenación estén legalmente afectados a fines determinados, o cuando se trate de valores o títulos representativos del capital de sociedades estatales que ejecuten políticas públicas o presten servicios de interés económico general». Precepto que se reproduce literalmente en el art. 23.1 de la Ley 47/2003, de 26 de noviembre, General Presupuestaria (LGP).

De esta forma, mientras el art. 173 de la LRHL incluye dentro de los bienes y derechos que no son susceptibles de embargo «los fondos» de la hacienda local; el art. 30.3 de la LPAP no hace referencia alguna a este concepto lo que plantea la problemática de determinar si, en la esfera local (al igual que en el caso de algunas Comunidades Autónomas), puede procederse contra los fondos de estas Administraciones.

50 Pueden consultarse, a este respecto dando prevalencia a la previsiones establecidas en la legislación patrimonial, las Sentencias dictadas sobre el particular por los Juzgados de lo Contencioso-Administrativo de Albacete y Ciudad Real (Sentencias núm. 222/2008 de 17 de noviembre de 2008 y núm. 362/2011 de 16 de diciembre de 2011 del Juzgado de lo Contencioso-Administrativo $n^{\circ} 1$ de Albacete, la Sentencia núm. 161/2012 de 14 de mayo de 2012 del Juzgado de lo Contencioso-Administrativo n. ${ }^{\circ} 2$ de Albacete y la Sentencia núm. 355/2013 de 29 de noviembre de 2013 del Juzgado de lo Contencioso-Administrativo ${ }^{\circ} 1$ de Ciudad Real) en las que según las cuales, «el Art. 3 de la Ley 33/2001, de 3 de noviembre, del Patrimonio de las Administraciones Públicas, define éste como el conjunto de sus bienes y derechos, cualquiera que sea su naturaleza y el título de su adquisición o aquél en virtud del cual les hayan sido atribuidos, pero excluye el dinero, los valores, los créditos y los demás recursos financieros de su hacienda (...)» (ST AB 362/2011) 
discutible problema ${ }^{51}$, lo que conduce a que inexorablemente a que sólo quedará solventado este asunto de forma definitiva si eventualmente se planteara una cuestión de inconstitucionalidad respecto de aquellos preceptos que se oponen a la inembargabilidad de los fondos públicos.

de donde hay que concluir que si el dinero no forma parte de los bienes y derechos patrimoniales de las Administraciones Públicas, nunca podrá ser afectado ni formal (art. 30.1 LPAP) ni materialmente (30.3 LPAP) a un servicio público o a una función pública y, en consecuencia, de conformidad con lo establecido en este precepto, siempre será embargable.

Asimismo, es de señalar que la Sentencia núm. 242/2013 dictada por la Sección 1. ${ }^{\text {a }}$ del Tribunal Superior de Justicia de Castilla-La Mancha el 11 de noviembre en el recurso de apelación interpuesto por la Junta de Comunidades de Castilla-La Mancha contra la núm. 362/2011 dictada por el Juzgado de lo Contencioso-Administrativo núm. 1 de Albacetel: «debe rechazarse la existencia de una presunción de inembargabilidad respecto de aquellos bienes que tengan la consideración de patrimoniales y en particular de los saldos que las administraciones públicas puedan tener en entidades bancarias» correspondiendo la carga de alegar y acreditar que se encuentran afectos materialmente a un servicio público a la administración embargada». Añadiendo que «el juego del contenido del art. 2 con la disposición final segunda» de la LPAP, refuerza la aplicación de la doctrina contenida en la STC 166/1998 para realizar una adecuada interpretación de los preceptos de aplicación a la inembargabilidad de los bienes de las Comunidades Autónomas que no han procedido a modificar su normativa propia «en esta materia para adecuarla a la interpretación constitucional del art. 132.1 CE»(...) «sin necesidad de plantear una cuestión de inconstitucionalidad sobre el particular».

51 MARTÍN FERNÁNDEZ, J y RODRÍGUEZ MÁRQUEZ, J., “¿Pueden las Entidades locales embargar a otros Entes públicos por impago de sus deudas tributarias?”, Quincena Fiscal n.17, 2007 opinan al respecto que "entendemos que sólo están sometidos al privilegio de inembargabilidad aquellos recursos que constituyan el Tesoro -en el Estado- o la Tesorería -en las Comunidades Autónomas y Entidades localesde los Entes públicos". Y siguen diciendo "Por tanto, debemos acudir, en principio, a los arts. 90 de la LGP y 175 del TRLHL para determinar este ámbito de inembargabilidad. Con arreglo al primero, «constituyen el Tesoro Público todos los recursos financieros, sean dinero valores o créditos de la Administración General del Estado y sus organismos autónomos, tanto por operaciones presupuestarias como no presupuestarias» . De conformidad con el segundo de los preceptos citados, «constituyen la Tesorería de las Entidades locales todos los recursos financieros, sean dinero, valores o créditos, de la Entidad local, tanto por operaciones presupuestarias como extrapresupuestarias». La lectura de ambos preceptos, casi idénticos, podría llevarnos a la conclusión de que cualquier tipo de recurso financiero forma parte de la Tesorería, ya que no se establece ningún tipo de distinción. Sin embargo, entendemos que se trata de una conclusión errónea, lo que se comprueba si se observan cuáles son las funciones atribuidas por la normativa al Tesoro o a la Tesorería. Así, los arts. 91 de la LGP y 177 del TRLHL señalan que su misión principal consiste en la recaudación de los derechos y el pago de las obligaciones, así como la distribución temporal de las disponibilidades dinerarias para la puntual satisfacción de las obligaciones.

La constatación anterior nos lleva a afirmar que sólo pueden considerarse integrantes del Tesoro aquellos recursos financieros con un alto grado de liquidez, característica esencial para poder cumplir las funciones que les encomiendan los preceptos indicados. Esta conclusión se confirma si acudimos al Plan General de Contabilidad Pública, que sólo considera como tesorería las inversiones financieras temporales, mientras que califica como inmovilizado las inversiones financieras permanentes. El criterio para distinguir entre unas y otras consiste en que su vencimiento sea o no superior a un año. Es decir, los recursos financieros que permanecen indisponibles durante el ejercicio presupuestario por tener un vencimiento que excede del mismo no tienen, para esta norma, la consideración de tesorería”. 
En segundo lugar, y por otro lado, la legislación patrimonial incluye dentro de los bienes y derechos no susceptibles de embargo, junto con los demaniales (esto es, los afectados al uso general o al servicio público - art. 4.1 y 65 y ss. de la LPAP-), una nueva categoría de bienes y derechos patrimoniales, que no son de dominio público, porque en este caso su embargabilidad estaría prohibida por el artículo apartado 1 de dicho artículo, pero que están materialmente afectados a un servicio público o a una función pública y, por ello, gozan de dicho privilegio. De esta forma, y a salvo de aquellos bienes y derechos que integran el domino público por estar afectos formal o materialmente a un uso o servicio público o cuando sus rendimientos o el producto de su enajenación estén legalmente afectados a fines determinados, tendrán carácter de embargables el resto de los bienes y derechos que integran el patrimonio de las Administraciones Públicas, siendo, eso sí, que la carga de alegar y acreditar su inembargabilidad va a corresponder a la Administración que lo esgrime frente a la ejecución del fallo.

\section{EJEGUGIÓN DE SENTENGIAS NO PEGUNIARIAS}

Las distintas previsiones realizadas en este aspecto por la legislación de 1998 resultaron, sin duda alguna y como ha sido puesto de manifiesto por la doctrina más solvente, uno de los aspectos más claramente novedosos, dado que el legislador concretó las medidas judiciales tendentes a su efectividad en defecto de cumplimiento voluntario por parte de la Administración (art. 108). Lo cierto, sin embargo, es que trascurridos veinte años desde su aprobación no puede afirmarse que las adoptadas hayan resuelto, en su totalidad, la problemática que presenta aquellas actuaciones administrativas que, por su naturaleza, no son susceptibles de ser sustituidas por otro sujeto aun cuando se trate de un órgano judicial. Precisamente por la mermada eficacia que en ocasiones puede tener el requerimiento judicial al efecto, el legislador de 1998 estableció medidas que, como las multas coercitivas, tienden a que sea secundado voluntariamente por la Administración.

\section{La ejecución de sentencias no pecuniarias}

En principio, el sistema procesal ejecutivo establecido reviste una doble vertiente: una de carácter positivo, que es acorde con el carácter sustitutivo de la actividad administrativa, y en la que se prevé la sustitución por los órganos jurisdiccionales, utilizando para ello, sus propios medios o los medios de la Administración demandada o de otras Administraciones (art. 108.1); y una segunda vertiente, en este caso de carácter negativo, en virtud de la cual se proscriben las ejecuciones aparentes y se sanciona la nulidad radical de los actos administrativos contrarios al fallo judicial (art. 108.2). 
Respecto de las medidas jurisdiccionales en orden a lograr la efectividad de la sentencia, aspecto positivo que mencionábamos, la norma contempla dos previsiones, de carácter genérico, que permiten diversas modalidades de ejecución según la naturaleza o carácter de la actividad o acto administrativo debidos.

En primer término, se da cobertura a la ejecución en forma específica, por cuanto el órgano jurisdiccional procederá a ejecutar la sentencia a través de sus «propios medios». En defecto de una específica delimitación legal sobre la naturaleza y entidad de dichos medios, en sentido estricto, los medios judiciales no parece que puedan exceder de los oportunos requerimientos de hacer, consistentes en el desarrollo de una actividad prestacional o la emisión de un acto administrativo, pudiendo asimismo instar la colaboración de las autoridades y agentes de la Administración condenada, o subsidiariamente de otras Administraciones públicas que deberán prestarla «con observancia de los procedimientos establecidos al efecto» [(art. 108.1 a) in fine)].

Sólo cuando la ejecución en forma específica devenga inviable podrá el juez adoptar «medidas de efecto equivalente», entre las que se incluye «la ejecución subsidiaria con cargo a la Administración condenada». Entre aquellas medidas cobran singular relieve el hacer a costa de la Administración, pero también la sustitución por el órgano jurisdiccional del acto administrativo omitido ${ }^{52}$, aunque la sustitución no podría consistir en la determinación judicial del contenido discrecional de los actos (art. 71.2).

\section{La ejecución por equivalencia}

La imposibilidad de la ejecución, que habrá de ser necesariamente sobrevenida con posterioridad al fallo judicial (así inclusive lo había establecido con anterioridad a la reforma la STC 41/1993 de 8 de enero), no puede basarse sino en que no es posible jurídicamente una declaración de voluntad judicial contraria al ordenamiento jurídico, o a la realidad material de un estado de $\operatorname{cosas}^{53}$, eso sí sin que una modificación normativa ulterior tenga eficacia para suspender la ejecución del fallo (ATS de 14 de febrero de 1984, RJ 1054). Debe partirse, por tanto, de que estamos frente a una situa-

52 Es ilustrativo el auto del Tribunal Supremo de 13 de marzo de 1986 (Ar. 1080) en el que el Tribunal declaró ajustada a Derecho la convocatoria judicial de una sesión extraordinaria para canalizar una moción de censura. Por su parte, la doctrina admite con carácter general el ejercicio de potestades administrativas actuadas desde el órgano judicial (REQUERO IBÁÑEZ, J. L., «Ejecución de sentencias en el proyecto de Ley de la Jurisdicción Contencioso-Administrativa. Procedimientos», en LA LEY, 1998-3, D-181).

53 Sobre la imposibilidad legal derivada de la derogación sobrevenida de la normativa aplicable al supuesto de hecho, puede consultarse el Auto del Tribunal Supremo de 30 de noviembre de 1994 (Archivo La Ley, 1995, 5191). En el mismo sentido, la imposibilidad de ejecutar en forma específica la sentencia firme por causa de la nueva regulación aplicable es corroborada por el Tribunal Supremo en el Auto de 19 de diciembre de 1994 (Ar. 10689). 
ción extraordinaria y excepcional del principio general de la ejecución en sus propios términos, carácter excepcional que justifica su aplicación restrictiva en todo caso.

En este sentido resulta ilustrativo el auto del Tribunal Supremo de 9 de julio de 1992 (La Ley, 1993-5, 4597). que, aun siendo anterior a la propia LJCA, sucesivamente rechaza la imposibilidad material y jurídica de ejecutar la sentencia anulatoria de la adjudicación de unos terrenos municipales, invocada por la Administración con base en la urbanización y adquisición de los inmuebles construidos por terceros de buena fe; en concreto, entiende el Tribunal Supremo que «... la necesidad de llegar a los acuerdos y celebrar los negocios oportunos no es obstáculo para que se deje sin efecto la adjudicación efectuada incurriendo en desviación de poder y para que el Ayuntamiento recupere la propiedad...», reiterando además la doctrina jurisprudencial ya sentada, según la cual «... la existencia de terceros hipotecarios no determina la imposibilidad de ejecución de la sentencia (no siendo) el incidente de inejecución (...) el momento procesal adecuado para pronunciarse sobre la protección hipotecaria y su posible conexión con la subrogación urbanística».

Una vez puesta de manifiesto por el órgano administrativo la imposibilidad de ejecución, que ha de revestir los caracteres de total y absoluta, la apreciación de su concurrencia es de libre valoración judicial y solo de ésta (STSJ de Castilla y León de 17 de julio de 2006, JUR 229615) que lo ha de hacer de forma motivada explicitando los motivos por los que la ejecución en sus propios términos no es posible, de tal manera que el derecho fundamental de los recurrentes quede salvaguardado mediante la ejecución por equivalente pecuniaria o por otro tipo de prestación, debiendo adoptar el juez, en su caso, «las medidas necesarias que aseguren la mayor efectividad de la ejecutoria». Fórmula legal notoriamente imprecisa y genérica y que entraña, como puede imaginarse, enormes dificultades.

Sin perjuicio de ello, y seguramente por ser consciente de la dificultad apuntada, se prevé la ulterior determinación judicial de la indemnización que proceda «en la parte que no pueda ser objeto de cumplimiento pleno» (art. 105.2 in fine), aunque ciertamente parece jerarquizarse o, al menos, subordinase los pronunciamientos judiciales siguientes a la apreciación de la imposibilidad, debiendo procurar el juez la mayor eficacia de la sentencia en lugar de acudir, en forma automática, a la indemnización de los daños y perjuicios ${ }^{54}$. De esta forma, la STS de 26 de mayo de 2008, (rec.

$54 \quad$ Es interesante poner de relieve, respeto al derecho indemnizatorio, la diferencia en la redacción del art. 18.2 de la LOPJ y el el artículo 105.2 LJCA y que fue objeto de análisis en la STS sentencia de 24 de enero de 2007, (rec. 140/2004), que declaró que «no deja de ser significativo que si bien el artículo 18.2 de la LOPJ), genérico y anterior en el tiempo, se refiere a la indemnización para estos supuestos "en todo caso", sin embargo, el posterior 105.2 de la LRJCA se refiere al mismo supuesto, para este orden jurisdiccional, señalando su procedencia solo "en su caso"; expresión de la que ya nos hemos ocupado en la STS de 10 de marzo de 2004 en la que se decía que: “(...) Si bien es cierto que no puede afirmarse con carácter absoluto 
89/2006), expone que: «Es cierto que, según el tenor de los dispuesto en el artículo 105.2 de la Ley reguladora de esta Jurisdicción, en los casos de imposibilidad legal o material de ejecutar la sentencia, la existencia de indemnización no es una consecuencia obligada y necesaria, sino que la norma legal, además de facultar al órgano sentenciador para apreciar la concurrencia de las causas de imposibilidad, le faculta también para adoptar las medidas necesarias que aseguren la mayor efectividad de la ejecutoria "fijando en su caso la indemnización que proceda..." (artículo 105.2 citado). La redacción del precepto indica que no es preceptivo que la indemnización exista en todo caso; y, en efecto, no la habrá cuando nadie la solicite"».

En cuanto a la fecha que debe tenerse en cuenta para el cálculo de la indemnización sustitutoria, la STS 19 de diciembre de 2012, (RG 6064/11), reitera que la fecha debe ser la del momento en que se declara la imposibilidad de ejecutar una sentencia y, en cuanto al alcance de la misma, se ha de acreditar ante el órgano judicial los daños y perjuicios derivados del incumplimiento del fallo y su valoración económica. La jurisprudencia, en este concreto aspecto, tiene admitido como tales los gastos procesales en que haya incurrido el peticionario en la sentencia dictada a su favor y que resultó de imposible ejecución, tales como honorarios de abogado, procurador y de peritos (sentencia del Tribunal Supremo de 4 de abril de 2013, (LA LEY 26876/2013). También se pronuncia en este sentido la sentencia del Tribunal Superior de Justicia de Galicia de 26 de febrero de 2015 (LA LEY 15821/2015) que engloba distintos conceptos indemnizables: «Partiendo del contenido del artículo 105 antes transcrito, se viene considerando en la jurisprudencia la procedencia de indemnizar los gastos procesales que le ha ocasionado el litigio, siempre partiendo de la necesidad de acreditar su cuantía; el daño moral derivado de que a pesar de que se cuenta con una sentencia favorable esta no se llevó finalmente a ejecución; y los perjuicios que de la inejecución de la sentencia se le deriven en su esfera patrimonial, en todo caso también acreditados»; y sobre los gastos procesales, señala expresamente: «Así ocurre con los gastos derivados de la existencia de varios litigios, que le han ocasionado la necesidad de pagar a los abogados, procuradores y peritos, cantidades que resultan detalladas para cada uno de ellos en primera instancia, en la ejecución, en el incidente de inejecución, y por la redacción de informes periciales; figuran las minutas y notas de derechos y suplidos; sin que se aprecie que sean cantidades

que las sentencias meramente declarativas o constitutivas no puedan ser objeto de ejecución forzosa, sí lo es que su ejecución reviste ciertas peculiaridades que no es posible ignorar. La ejecución es posible en aquellos casos en que, simultáneamente con la declaración de nulidad o anulabilidad del acto, se produce el reconocimiento de una situación jurídica individualizada y sea preciso adoptar las medidas legales necesarias para que ese reconocimiento resulte efectivo, o las indemnizaciones sustitutorias pertinentes en el caso de que no fuese material o legalmente posible efectivizar el reconocimiento; y a esa misma conclusión hemos de llegar (Sentencia de esta Sala de 29 de octubre de 2.001) cuando la efectivización del fallo requiera una actividad ejecutiva de cualquier clase que sea». 
excesivas; y siendo cierto que ejercitó sus acciones voluntariamente, también lo es que a ello responde el derecho a la tutela judicial efectiva».

Todo este conjunto de cuestiones debe ser objeto de análisis por el órgano jurisdiccional y por lo tanto conducen a una interpretación mucho más amplia que la regulada en la LEC, debiendo ponderar el órgano jurisdiccional, en cada caso, si existe o no pronunciamiento ejecutable.

Desde el punto de vista procedimental, la decisión judicial sobre la concurrencia de la imposibilidad de ejecución debe ser adoptada por vía incidental (art. 109.1), con audiencia de las partes y de quienes el juez ejecutor considere interesados, bien es cierto que ha sido criticado por la doctrina, muy singularmente LOZANO CUTANDA $^{55}$, el reconocimiento en exclusiva al representante procesal de la Administración de legitimación para plantear el incidente que parecía haberse superado en la jurisprudencia del Tribunal Supremo respecto de lo previsto en la legislación anterior (Auto de 21 de marzo de 1988, RJ 2241).

Respecto de la expropiación de los derechos e intereses legítimos reconocidos en sentencia por causa de utilidad pública o interés social, el art. 18.2 de la Ley Orgánica del Poder Judicial legitimó dicha declaración gubernamental, si bien no individualizó las situaciones jurídicas que podían cobijarse al amparo de tales títulos lo que fue objeto de crítica por la doctrina por entenderla más regresiva que la situación anterior ${ }^{56}$. El legislador de 1998, en aras de la seguridad jurídica y como garantía de los administrados, enumera las situaciones jurídicas que son presupuesto de la misma, a saber: el peligro cierto de alteración grave del libre ejercicio de los derechos y libertades de los ciudadanos, el temor fundado de guerra y el quebranto de la integridad del territorio nacional (art. 105.3), supuestos estos dos últimos de difícil inteligencia pues resulta complicado, al menos, que de la ejecución de una sentencia puedan derivarse tales efectos. El legislador huye deliberadamente así, como señaló oportunamente GONZÁLEZ PEREZ, de la posible alteración del «orden público», evitando así que su indeterminación conceptual pueda servir de pretexto gubernamental para «pisotear la Ley y el Derecho» ${ }^{57}$.

En contraposición al carácter objetivo que reviste la imposibilidad material o jurídica de la ejecución, en la potestad expropiatoria subyacen consideraciones de oportunidad política, y más concretamente, de política exterior y de seguridad nacional. Igualmente, frente a la apreciación judicial de la imposibilidad de la ejecución,

55 LOZANO CUTANDA, B., Comentarios a la Ley de la furisdicción Contencioso-Administrativa, Civitas, Madrid, 1999.

56 GARCÍA DE ENTERRÍA, E. y FERNÁNDEZ RODRÍGUEZ, T.R. (2000).

57 GONZÁLEZ PÉREZ, J., Comentarios a la Ley de la furisdicción Contencioso-Administrativa, Civitas, Madrid, 2016, pág. 737. 
la expropiación procede ab initio con base en una declaración gubernamental -ya del Gobierno nacional o el autonómico-, si bien respecto de la afectación del ejercicio de los derechos y libertades de los ciudadanos se impone el control judicial a posteriori, tanto del peligro cierto de alteración grave de su ejercicio como, en su caso, de la determinación de la indemnización compensatoria derivada de la expropiación, pues no otro sentido puede tener la previsión legal según la cual, el «juez o Tribunal... apreciará, además, la concurrencia de dicho motivo» (art. 105.3. in fine).

Desde el punto de vista competencial la Ley introdujo como novedad, respecto de la normativa anterior, la posible declaración expropiatoria del Consejo de Gobierno de una Comunidad Autónoma cuando estando involucrada la afectación del ejercicio de derechos y libertades de los ciudadanos, el acto o la disposición impugnados proviniera de los órganos de la Administración autonómica o de las Entidades locales, así como de Entidades de Derecho público y Corporaciones dependientes de aquéllos. Se excluyó pues, a mi juicio sin ninguna justificación, a los entes locales de dicha posibilidad que deberán instarlo a los órganos de gobierno autonómicos.

Finalmente la Ley, tratando de evitar cualquier maniobra elusiva por parte de la Administración, establece un plazo preclusivo a la declaración expropiatoria: dos meses desde la comunicación judicial de la sentencia. Y comunicada dicha imposibilidad el juez o Tribunal señalará por la vía incidental la indemnización que corresponda a los afectados.

En cuanto a la declaración judicial de nulidad de los actos y disposiciones contrarios al fallo judicial, entendemos que debe concluirse asépticamente del análisis del contenido de aquellos, obviando cualquier toma en consideración del elemento culpabilístico por parte de la Administración, y correlativamente, relegando al interesado de la carga de su prueba. En consonancia con tal declaración el juez deberá «reponer la situación al estado exigido por el fallo y determinará los daños y perjuicios que ocasionare el incumplimiento» (art. 108.2), los cuales eventualmente, podrán derivarse no sólo para el ejecutante, sino para cualesquiera otros interesados a la vista del contenido material de los actos y disposiciones que se anulan.

Aunque en aras de la más expeditiva efectividad de la sentencia la ley prevea la sustanciación de la pretensión de nulidad por el trámite incidental, no podemos desconocer que se trata de una pretensión impugnatoria de carácter autónomo que, como tal, excede el ámbito de la competencia funcional del juez ejecutor (art. 7.1), obligando a conjugar ex novo las normas generales de competencia objetiva y territorial; de ahí, que la ley confirme la competencia del órgano jurisdiccional a quien corresponda la ejecución, a menos que «careciese de competencia para ello conforme a lo dispuesto en esta Ley» (art. 103.5 in fine). 


\section{Medidas compulsivas tendentes al cumplimiento del fallo en obligaciones no pecuniarias}

El legislador de 1998 contempló diversas medidas, de carácter compulsivo, dirigidas a que la Administración cumpliera en forma estricta lo dispuesto en el fallo. de la sentencia. Su origen precisamente se encuentra, como destaca GONZÁLEZ PÉREZ, en las prerrogativas de la Administración que dificultan la ejecución procesal y que aconsejaron la adopción en las legislaciones contencioso-administrativas de los países de nuestro entorno de medidas indirectas para posibilitar el cumplimiento efectivo de las sentencias ${ }^{58}$.

Sin perjuicio de las que se prevén específicamente, con carácter imperativo dado el verbo utilizado por la norma, para condenas en que se establece el pago de una cantidad a las que nos referimos, en este momento analizaremos las que, con carácter general, se contempla para todo tipo fallos - ya que la norma no realiza distinción alguna- aunque específicamente, y por su naturaleza, más propias para fallos en que se contemplen medidas no pecuniarias, a saber: de un lado, la imposición de multas coercitivas; y, de otro, el libramiento de testimonio al juez penal para que eventualmente se deduzcan responsabilidades penales. Bien es cierto que el artículo 112 no excluye otras consecuencias del incumplimiento o cumplimiento indebido del fallo como las responsabilidades patrimoniales que se derivasen del mismo lo que conlleva una remisión a la legislación de régimen jurídico y procedimental común.

Como, en su momento, puso de manifiesto SENÉS MOTILLA las multas coercitivas y el testimonio judicial presentan notables diferencias, tanto en lo que se refiere a su naturaleza jurídica y contenido, como en lo atinente a su finalidad ${ }^{59}$. En cualquier caso, lo cierto es que no se trata de medidas sustitutivas de lo previsto en el fallo sino que, por el contrario, se dirigen precisamente al cumplimiento de lo previsto en el mismo. Cabe señalar, asimismo, que aun cuando la norma no otorga preferencia alguna a una medida o a otra cabe deducir, a tenor del artículo 48, que en primer término habrán de imponerse las multas coercitivas y, si se sigue desa-

58 GONZÁLEZ PÉREZ, J. (2016: 1019).

59 SENÉS MOTILLA, C., "La ejecución de sentencias en la nueva Ley de la Jurisdicción Contencioso-Administrativa" Diario La Ley, Sección Doctrina, Tomo VI, 1998 para quien en rigor, sólo las multas coercitivas constituyen un mecanismo compulsivo proclive al cumplimiento de la sentencia por las autoridades, funcionarios o agentes previamente requeridos y apercibidos judicialmente; no así, el libramiento al juez penal del testimonio de particulares por presunta desobediencia judicial (art. 410.1 del Código Penal) que supone el cumplimiento por el juez contencioso-administrativo del deber de promover la perseguibilidad de los ilícitos penales de que tenga conocimiento (art. 162 de la Ley de Enjuiciamiento Criminal). En este sentido, baste reparar en el ámbito competencial que incumbe al juez de lo contencioso en uno y otro caso como confirmación de lo que decimos; así, a la determinación judicial de la procedencia, frecuencia y cuantificación de la multa coercitiva, se contrapone la mera deducción del tanto de culpa, sin que la apreciación del juez de lo contencioso tenga valor prejudicial alguno en el juicio Jurisdiccional penal. 
tendiendo los requerimientos, proceder por parte del Juez o Tribunal, pues no otro sentido parece que ha de darse al apartado 10 del artículo 48 al prever que impuestas las tres primeras multas coercitivas sin lograr que se remita el expediente completo, a poner los hechos en conocimiento del Ministerio Fiscal, sin perjuicio de seguir imponiendo nuevas multas y exigir que el requerimiento cuya desatención pueda dar lugar a la tercera multa coercitiva contenga el oportuno apercibimiento. Es relevante asimismo recordar que la imposición de multas coercitivas, reiteradas en el tiempo, no participa de la naturaleza sancionadora, si bien no es menos cierto que debe regirse por los principios propios de éstas en consideración a la finalidad que persiguen.

La adopción de las mismas se condiciona, amén del ya expuesto de deducción del tanto de culpa, por la norma a tres requisitos: en primer término, que hayan transcurrido los plazos para el total cumplimiento del fallo; el segundo, relativo a que se realice un previo apercibimiento; y, por último, la audiencia de las partes.

Respecto del primero, es preciso remitirse a lo dispuesto en el artículo $104 \mathrm{y}$ así habrán de transcurrir dos meses a partir de la comunicación de la sentencia o el plazo fijado en ésta para el cumplimiento del fallo.

En cuanto al segundo, el mandato debe ser expreso, terminante, claro, obligatorio y de cumplimiento posible. Si la orden es de cumplimiento imposible, no se cumple la finalidad ya que el deber de obedecer sólo surge cuando los mandatos reúnen las condiciones exigidas por el ordenamiento jurídico. En este sentido, el incumplimiento de lo ordenado por imposibilidad de la obligación no supone delito de desobediencia ni puede ser presupuesto de hecho para la imposición de multas coercitivas. Si la obligación es originariamente imposible (porque no es competencia del órgano), o deviene imposible con el tiempo (porque la persona ha dejado de ostentar el cargo) no se reúnen los requisitos necesarios para la adopción de las citadas medidas en forma individualizada.

Respecto del tercero, es importante señalar la importancia de que el mismo se dirija, no con carácter genérico a la Administración, sino específicamente al órgano encargado de la ejecución del fallo a fin de evitar que las mismas se dicten inaudita parte, y sin posibilidad por tanto de alegaciones por la ejecutada ni por terceros que posiblemente resultarán afectados, toda vez que, como destaca la Sentencia del Tribunal Constitucional de fecha 26 de febrero de 2001 (recurso no 1598/1998): "Este Tribunal ha declarado reiteradamente que el derecho a la tutela judicial efectiva sin indefensión (art. 24.1 CE) garantiza a todos los que puedan resultar afectados por la decisión que se dicte en un proceso judicial el derecho a conocer su existencia, a fin de que tengan la posibilidad de intervenir en él, ser oídos, y ejercer la defensa de sus derechos e intereses legítimos. Ello impone a los órganos judiciales un especial deber de diligencia en la realización de los actos de comunicación procesal, que asegure, en 
la medida de lo posible, su recepción por los destinatarios, dándoles así la oportunidad de defensa. Este deber de diligencia tiene especial importancia en el proceso de ejecución, pues el derecho a la tutela judicial efectiva habilita a quienes ostente algún derecho o interés legítimo, que pueda verse afectado, para comparecer y actuar en el procedimiento, aunque no hubiera sido parte en el proceso principal, y a este fin los art. 270 LOPJ y 2602 LECivil exigen que las resoluciones judiciales se notifiquen no sólo a las partes procesales sino también a las personas a quienes se refieran o puedan parar perjuicio".

En relación a la imposición de multas pecuniarias, la Ley no establece criterio alguno a fin de modular la cuantía de la multa, previendo su oscilación entre 150 y 1500 euros hasta la completa ejecución de la sentencia, lo que lleva a que la discrecionalidad otorgada por la norma deba equilibrarse con la apreciación del órgano jurisdiccional de «la resistencia al cumplimiento» por parte del órgano encargado de la ejecución de la sentencia lo que habrá de calibrarse en la audiencia previa a la decisión judicial sobre la imposición de la multa.

La imposición de estas multas, por expresa remisión de la Ley, se rige por lo dispuesto en el artículo 48 para las multas procedentes por la falta de remisión del expediente administrativo. En este sentido, les será de aplicación la frecuencia con que deberá reiterarse la multa hasta el cumplimiento de lo requerido (veinte días); la responsabilidad pecuniaria inmediata de la Administración -que deberá hacer frente al pago de la multa- en defecto de la individualización de la autoridad o empleado responsable del incumplimiento; la impugnación judicial frente a su imposición («audiencia en justicia»); y, por último, la exacción de la multa por la vía de apremio.

En cuanto al apercibimiento de deducir testimonio de particulares al juez penal, al ser reiteradamente desatendido el requerimiento judicial (artículo $410 \mathrm{CP})^{60}$,

60 Cabe remitirse aquí, en cuanto a los requisitos del tipo, a la sentencia de la Audiencia Provincial de Lleida de 14 de septiembre de 2006 (ARP 2007, 217). Más recientemente la Sentencia 40/2015, de 4 de noviembre de la Sección $1^{\circ}$ de la AP de Lleida advierte, sin embargo, que: «A mayor abundamiento debemos señalar que no siempre que una sentencia o resolución judicial resulte incumplida por el obligado a ello, nos encontramos ante un ilícito penal, pues para el caso de que una resolución no sea cumplida de forma voluntaria, la Ley prevé medidas de ejecución forzosa, antes de que tal incumplimiento pueda considerarse constitutivo de delito. En definitiva, la legitimación de la intervención del Derecho Penal ha de estar basada en la presencia de comportamientos que denoten o lleven implícito un plus de gravedad, pues el citado derecho no puede convertirse en un instrumento sancionador de conductas, cuyos remedios, prevén las leyes procesales en vía civil, con posibilidades reales de garantizar una tutela suficiente al ejecutante, pues en caso contrario se menoscabaría el principio de intervención mínima de dicho sector del ordenamiento jurídico».

De esta forma, como destaca GONZALEZ PÉREZ, J. (2016:1050), así configurado el tipo, que en la jurisprudencia exige una abierta negativa, es complejo que se condene ya que lo normal será una actitud pasiva pero no negarse abiertamente a ejecutar lo dispuesto en la sentencia. Pueden verse, asimismo, las SSTS de 16 de marzo de 1993 (RJ 2311) en la que se condena a un Alcalde que no solo omitió el cumpli- 
como ha señalado SENÉS MOTILLA, la disparidad institucional entre la imposición de multas coercitivas y ésta hace inviables jurídicamente algunas previsiones legales, tales como el «previo apercibimiento» del Secretario judicial, que si bien tiene sentido respecto de una multa coercitiva - por cuanto puede bastar para forzar el cumplimiento voluntario de la Administración-, carece de sentido respecto del deber de denunciar un hecho que reviste caracteres de delito, pues en modo alguno dicho apercibimiento constituye un requisito de procedibilidad para proceder penalmente. Lo mismo puede decirse, aunque de forma parcial, respecto de la previa audiencia a las partes, que sirviendo a la apreciación judicial de los factores que permiten individualizar la multa, sólo tiene sentido respecto del delito de desobediencia con el fin de vislumbrar la «abierta negativa» a dar cumplimiento a la resolución judicial ${ }^{61}$.

\section{LA EJEGUCIÓN IMPROPIA}

El art. 107 LJCA aborda lo que se viene denominando «ejecución impropia» de aquellos fallos, de carácter declarativo, a los que nos referimos con anterioridad; ejecución impropia que pasa sencillamente por la inscripción registral y la publicación del fallo en los términos que a continuación se desgranan y que no implican, en principio, estrictamente una actividad ejecutiva. Como ya señalamos, asimismo, no es dable concluir que en estos supuestos se excluye de forma absoluta una actividad judicial de estricta ejecución pues, como se razona, en la Sentencia de 2 de marzo de 2016 (Rec. 1626/2015) puede haber supuestos en que el cumplimiento de una sentencia que anula un acto o una disposición de carácter general no se agote con su publicación (cabe mencionar a título de ejemplo aquéllos en que se actúan potestades regladas y no discrecionales), y habrá de estarse siempre a las circunstancias de cada caso y en particular a los términos del fallo que hay que ejecutar teniendo en cuenta que la prohibición establecida en el artículo 71.2 LJCA opera como es lógico no solo al dictarse la sentencia sino también a la hora de ejecutarla.

En lo que se refiere a la primera de las previsiones, la inscripción registral y publicación de sentencias anulatorias de actos administrativos singulares, referidos ambos supuestos estrictamente a actos administrativos de carácter singular, la regla general establecida es que si la sentencia anula total o parcialmente un acto impugnado el órgano judicial — en concreto el Secretario Judicial—, y siempre a instancia de parte podrá adoptar dos clases de medidas: de una parte, la inscripción del fallo en los registros públicos a que hubiere tenido acceso el acto anulado; y, por otra, su

miento sino que, asimismo, indujo a adoptar determinados acuerdos elusivos del cumplimiento íntegro y efectivo y la de 6 de febrero de 2006 (RJ 367) en que los concejales, advertidos por el Alcalde, adoptaron acuerdos dirigidos al incumplimiento.

61 SENÉS MOTILLA, G. (1998). 
publicación en los periódicos oficiales o privados siempre que concurra causa bastante para ello. En ambos casos a costa de la parte ejecutada, pero además, en el supuesto de su publicación en periódicos privados, se somete a su vez a un requisito añadido que consiste en la necesidad de acreditar ante el órgano judicial de la presencia de un interés público que justifique la publicación.

Se trata, pues, con la primera medida relativa a la inscripción, de acceder al Registro al que tuvo acceso el acto, ya se trate de dar acceso al fallo de la sentencia a aquellos Registros en los que figurase inscrito el acto anulado, ya fuera de aquellos Registros a los que se hubiese denegado la inscripción, bien por el propio responsable del Registro, bien por negarse a realizarla la Administración autora ${ }^{62}$. Y aun cuando la LJCA no lo contemple expresamente se han de entender incluidos aquellos Registros a los que dicho acto debió haber accedido.

En cuanto a la segunda medida de las previstas, la publicación del fallo en periódicos oficiales y privados, la LJCA lo condiciona, utilizando conceptos jurídicos indeterminados ${ }^{63}$, a dos requisitos: el primero, de carácter general y de aplicación por tanto a la publicación en medios oficiales y privados, a que concurra causa bastante para ello lo que parece ha de traducirse, con carácter general, en que, cuando el fallo de la sentencia hubiese anulado actos o disposiciones con efectos negativos en la esfera personal o profesional de los que fueron parte en el proceso, se restablezca la honorabilidad o prestigio de éstos y, en caso de que se tratase de terceros que no fueron parte en el proceso, que los mismos tengan acceso al fallo que protege sus intereses mediante la publicación del mismo; el segundo, de nuevo con la atribución al órgano judicial de una amplia discrecionalidad, para como hemos dicho publicarse en medios privados cuando concurra no solo causa bastante, sino además que concurra un interés público, es decir, que existan razones suficientes para estimar que el fallo de la sentencia ha de tener, por su trascendencia, público conocimiento.

No contempla la norma requisito alguno procedimental para proceder a la adopción de dichas medidas ya que, ni se establece plazo alguno, a salvo de que se exprese en la sentencia o en el auto de ejecución, para efectuarlo lo que puede tener especial relieve para satisfacer la finalidad que se persigue, ni se imponen cargas procedimentales que, como la audiencia a la Administración ejecutada, cobran especial sentido ya que ésta ha de hacerse cargo de los gastos que se generen.

${ }^{62}$ En realidad, y como puntualiza FERNANDEZ VALVERDE, R., "Urbanismo y ejecución de sentencias", en el volumen colectivo La ejecución de sentencias contencioso-administrativas (coord. SANCHEZ LAMELAS, A.), Thompson-Aranzadi, Navarra, 2006, pág. 88, aunque el precepto utilice la expresión "inscripción", el mismo, no obstante, no puede ser entendido en términos estrictos de carácter registral, sino en un sentido amplio y con independencia de los efectos que el fallo pudiera producir en el ámbito del registro de que se trate.

63 Puede verse a este respecto GONZÁLEZ PÉREZ, J. (2016: 1019). 
Por último, y en lo que se refiere a sentencias cuyos fallos dispusiesen la nulidad de actos administrativos generales o disposiciones administrativas de carácter general, el artículo art. $107 \mathrm{LJCA}$, reiterando en forma innecesaria lo ya establecido por el artículo 72.2 LJCA salvo el plazo establecido para ello, establece que el órgano judicial ordenará de oficio la publicación, en el plazo de diez días a contar desde la firmeza de la sentencia que disponga tal conclusión anulatoria lo que encuentra su natural razón de ser, tanto en la protección de los derechos e intereses legítimos de terceros que no fueron parte del proceso, como en el de que una anulación de una disposición administrativa de carácter general y su correlativa expulsión del ordenamiento jurídico implica, se quiera o no, una modificación de éste que, precisamente por ello, justifica su general conocimiento mediante su publicación en el diario oficial que corresponda.

Bien es cierto que, sentada esa primera afirmación, también ha de advertirse que el alcance de las declaraciones de nulidad de pleno derecho que pueden hacer los tribunales en estos supuestos no es absoluto. Si como sabemos, y atendiendo a la doctrina establecida con carácter general, dicha especie de nulidad tiene efectos ex tunc, es decir, que los efectos de la nulidad no se producen a partir de su declaración, sino que se retrotraen al momento mismo en que se dictó la disposición declarada nula afectando, por tanto, a todas las actuaciones que amparadas en la misma se hubiesen producido ${ }^{64}$, no debe dejar de ponerse de relieve en este punto que dicha inicial conclusión se ha visto atemperada por la propia jurisprudencia.

De esta forma, y limitando los efectos de la declaración de nulidad de pleno derecho, también la jurisprudencia ha declarado la subsistencia de los actos firmes dictados en aplicación de la disposición general declarada nula (que resultaban intangibles pese a la declaración de nulidad de aquélla), equiparando la anulación a la derogación, en que los efectos son "ex nunc" y no "ex tunc", si bien sólo respecto a los actos firmes, permaneciendo en cuanto a los no firmes la posibilidad de impugnarlos en función del ordenamiento jurídico aplicable una vez declarada nula la disposición

64 La Sentencia de 2 de marzo de 2015 del Tribunal Supremo (Sala de lo Contencioso-Administrativo, Sección $5^{\text {a }}$; RJ 2015 \1782) reitera, con referencia a la jurisprudencia ya existente en la materia, que: «Esta sentencia estima el contencioso-administrativo con base en reiterada jurisprudencia de esta Sala -así sentencias de 8 de abril (RJ 2010, 2775) y 21 de mayo de 2010 (RJ 2010, 5191) y 15 de junio de 2012 (RJ 2012, 9102) - que en esencia, declararon que (1) los planes de urbanismo son disposiciones de carácter general, esto es, son normas con rango reglamentario, de modo que no puede resultar de aplicación el artículo 67 de la Ley 30/1992, (2) los vicios de los que adolecen las disposiciones generales son vicios de nulidad plena, respecto de los cuales carece de fundamento la convalidación, (3) los vicios de invalidez en que pueden incurrir las disposiciones generales son únicamente supuestos de nulidad plena, y (4) la nulidad de pleno derecho no admite convalidación, pues no se trata de un simple supuesto de anulación sino de nulidad con efectos ex tunc. En definitiva, se trata de los efectos lógicos de la declaración de nulidad de pleno derecho de una disposición reglamentaria. 
general [puede verse a este respecto las Sentencias dictada por el Tribunal Supremo de fechas 31 de enero de 2000 (RJ 2000, 1929) y 19 de octubre de 2011 (RJ 2012, 1302), rec. 6157/2008] ${ }^{65}$. Excepción, esta última, fundamentada en el principio de seguridad jurídica, que implica una limitación temporal de los efectos ex tunc para evitar los efectos retroactivos sobre situaciones jurídicas consolidadas. Y excepción que hoy encuentra apoyo inequívoco en el artículo 73 de la LJCA ${ }^{66}$.

65 La STS de 17 de junio de 2009 (RJ 2009, 5785) (rec. n 5491/2007), haciendo suyo lo declarado en la STS de 4 de enero de 2008 (RJ 2008, 1587), dispondrá que: «Ciertamente, esta Sala Tercera del Tribunal Supremo, interpretando antes lo establecido en los artículos 120 de la Ley de Procedimiento Administrativo de 1958 y 86.2 de la Ley de la Jurisdicción Contencioso-Administrativa de 1956, y ahora lo dispuesto en los artículos 102 de la Ley 30/1992, de Régimen Jurídico de las Administraciones Públicas y de Procedimiento Administrativo Común, y 73 de la Ley de la Jurisdicción Contencioso -Administrativo 29/1998, ha declarado que por razones de seguridad jurídica se atempera el principio de eficacia erga omnes de las sentencias anulatorias de las disposiciones de carácter general respecto de los actos administrativos que hubiesen adquirido firmeza con anterioridad a que la sentencia anulatoria de aquellas disposiciones alcanzase efectos generales (Sentencias, entre otras, de fechas 26 de febrero de 1996 (RJ 1996, 1391), 28 de enero y 23 de noviembre de 1999 (RJ 1999, 9767), 24 y 26 de julio de 2001 y 14 de julio de 2004 (RJ 2004, 5602), y concretamente se ha declarado que la anulación de los instrumentos de planeamiento deja a salvo las licencias firmes (Sentencia de fecha 8 de julio de 1992 (Rf 1992, 6157)».

66 En efecto dicho precepto establece que: "Las sentencias firmes que anulen un precepto de una disposición general no afectarán por sí mismas a la eficacia de las sentencias o actos administrativos firmes que lo hayan aplicado antes de que la anulación alcanzara efectos generales, salvo en el caso de que la anulación del precepto suponga la exclusión o la reducción de las sanciones aún no ejecutadas completamente". 


\section{BIBLIOGRAFÍA}

ARANGUREN PÉREZ, I. Y GONZALEZ RIVAS, J., Comentarios a la Ley de la Furisdicción Contencioso-Administrativa, $2^{\text {a }}$ Edición, Thompson-Civitas, Navarra, 2008.

BELTRAN DE FELIPE, M., El poder de sustitución en la ejecución de sentencias condenatorias de las Administración, Madrid, Civitas, 1995.

BERROCAL ACEDO, A., "IIntegra el artículo 108.3 LJCA un supuesto de suspensión de la ejecución de sentencia?”, Actualidad administrativa, $\mathrm{N}^{\circ}$ 2, 2018.

FERNÁNDEZ TORRES, J.R., Historia legal de la jurisdicción contencioso-administrativa (1845-1998), Madrid, Iustel, 2007.

FERNANDEZ VALVERDE, R., "Urbanismo y ejecución de sentencias", en el volumen colectivo La ejecución de sentencias contencioso-administrativas (coord. SANCHEZ LAMELAS, A.), Thompson-Aranzadi, Navarra, 2006.

GALAN GALAN, A., "Los poderes del Juez en la ejecución de sentencias: reacción frente a los actos de la Administración o del legislador que tengan como finalidad eludir su cumplimiento", en el volumen colectivo La ejecución de sentencias contencioso-administrativas (coord. SANCHEZ LAMELAS, A.), Thompson-Aranzadi, Navarra, 2006.

GARCÍA DE ENTERRÍA, E. y FERNÁNDEZ RODRÍGUEZ, T. R.: Curso de Derecho Administrativo, Ed. Civitas. Madrid, 2000.

GÓMEZ-FERRER RINCÓN, R., La imposibilidad de ejecución de sentencias en el proceso contencioso-administrativo, Thomson-Civitas, Madrid, 2008.

GONZALEZ PÉREZ, J., Comentarios a la Ley de la Jurisdicción Contencioso-Administrativa, Civitas, Madrid, 2016, pág. 1045.

GONZALEZ VARAS-IBAÑEZ, S. Comentarios a la Ley de la jurisdicción contencioso-administrativa : (Ley 29/1998, de 13 de julio), adaptados a la nueva concepción subjetiva, Madrid, Tecnos, 1999.

IBAÑEZ LÓPEZ, F. Y IBAÑEZ LOZANO, F., "La superación de la doctrina constitucional contenida en la Sentencia 166/1998, de 15 de julio, por lo que se refiere a la inembargabilidad del dinero y ciertos bienes patrimoniales de las administraciones públicas", El Consultor de los Ayuntamientos y los Fuzgados, No 4, 2016.

JIMÉNEZ BUESO, A., "Modificaciones de planeamiento y ejecución fraudulenta de sentencias en materia de urbanismo", Práctica Urbanística, no 105, Ed. La Ley, Madrid, Junio 2011. 
LÓPEZ GIL, M., Avances en la ejecución de sentencias contra la Administración, Thompson-Aranzadi, Navarra, 2004.

LOZANO CUTANDA, B., Comentarios a la Ley de la Jurisdicción Contencioso-Administrativa, Givitas, Madrid, 1999.

MARTÍN DELGADO, I., La ejecución subrogatoria de las sentencias contencioso-administrativas, Madrid, Iustel, 2006.

MARTÍN FERNÁNDEZ, J y RODRÍGUEZ MÁRQUEZ, J., “¿Pueden las Entidades locales embargar a otros Entes públicos por impago de sus deudas tributarias?", Quincena Fiscal n'.17, 2007.

MUÑOZ MACHADO, S., La reserva de jurisdicción, Madrid, Wolters Kluwer, 1989.

RAZQUIN LIZÁRRAGA, J. A., "Tutela judicial efectiva e imposibilidad legal de ejecución de sentencias en materia de urbanismo", en Revista Aranzadi Doctrinal, $\mathrm{n}^{\mathrm{o}}$ 3, Ed. Aranzadi, Pamplona, 2009.

REQUERO IBÁÑEZ, J. L., «Ejecución de sentencias en el proyecto de Ley de la Jurisdicción Contencioso-Administrativa. Procedimientos», Diario La Ley, 1998-3, D-181.

SANCHEZ GOYANES, E., "Problemática en la ejecución de sentencias urbanísticas", Revista de Estudios Locales, GUNAL, n 178, 2015.

SENÉS MOTILLA, G., "La ejecución de sentencias en la nueva Ley de la Jurisdicción Contencioso-Administrativa" Diario La Ley, Sección Doctrina, Tomo VI, 1998.

SUAREZ GARCÍA, J., "Algunos ejemplos prácticos de la difícil ejecución de sentencias contencioso-administrativas", en el volumen colectivo La ejecución de sentencias contencioso-administrativas (coord.. SANCHEZ LAMELAS, A.), Thompson-Aranzadi, Navarra, 2006. 